Prepared in cooperation with the U.S. Army Corps of Engineers

\title{
Near-Surface Stratigraphy and Morphology, Mississippi Inner Shelf, Northern Gulf of Mexico
}

By James Flocks, Jack Kindinger, Kyle Kelso, Julie Bernier, Nancy DeWitt, and Michael FitzHarris

Open-File Report 2015-1014

U.S. Department of the Interior

U.S. Geological Survey 


\section{U.S. Department of the Interior \\ SALLY JEWELL, Secretary}

\section{U.S. Geological Survey \\ Suzette M. Kimball, Acting Director}

U.S. Geological Survey, Reston, Virginia: 2015

For more information on the USGS—-the Federal source for science about the Earth,

its natural and living resources, natural hazards, and the environment-visit

http://www.usgs.gov or call 1-888-ASK-USGS

For an overview of USGS information products, including maps, imagery, and publications, visit http://www.usgs.gov/pubprod

Any use of trade, firm, or product names is for descriptive purposes only and does not imply endorsement by the U.S. Government.

Although this information product, for the most part, is in the public domain, it also may contain copyrighted materials as noted in the text. Permission to reproduce copyrighted items must be secured from the copyright owner.

Suggested citation:

Flocks, James, Kindinger, Jack, Kelso, Kyle, Bernier, Julie, DeWitt, Nancy, and FitzHarris, Michael, 2014, Nearsurface stratigraphy and morphology, Mississippi inner shelf, northern Gulf of Mexico: U.S. Geological Survey Open-File Report 2015-1014, 19 p.,

http://dx.doi.org/10.3133/ofr20151014

ISSN 2331-1258 (online) 


\section{Acknowledgments}

The authors would like to thank the crew of the R/V Tommy Munro along with USGS technician Dana Wiese for their assistance with data collection and processing. Funding was provided by the U.S. Army Corps of Engineers and the U.S. Geological Survey. We also appreciate the reviews of Stanley Locker and Karen Morgan of the U.S. Geological Survey St. Petersburg Coastal and Marine Science Center. 


\section{Contents}

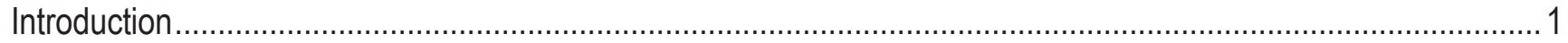

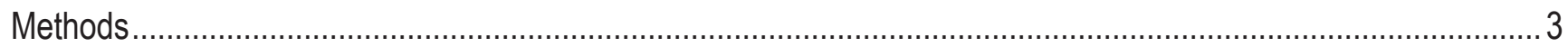

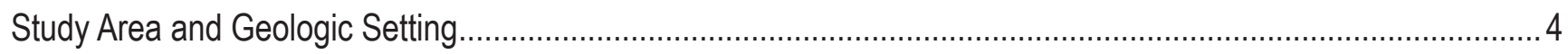

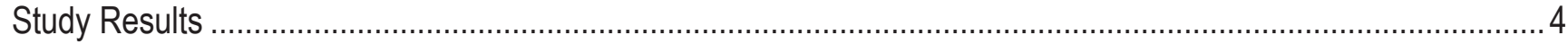

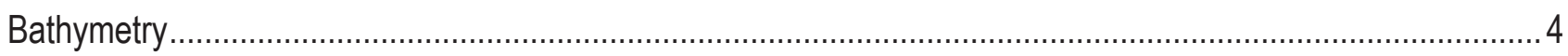

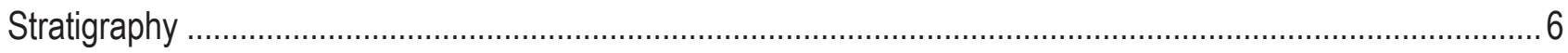

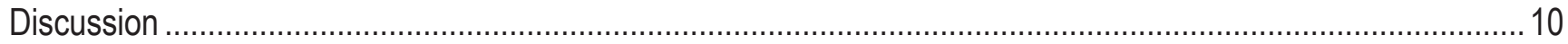

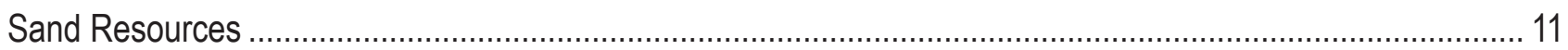

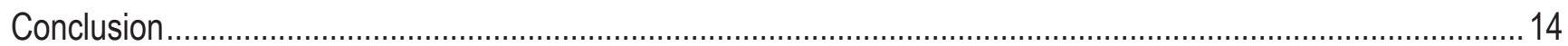

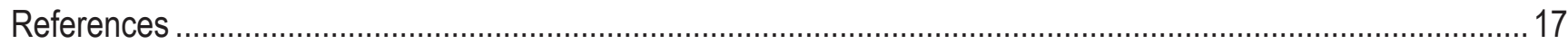




\section{Figures}

1. Satellite image showing islands and inlets of the Gulf Islands National Seashore and surrounding area.....1

2. Tracklines of the geophysical data collected and locations of sediment cores used in this report.

3. Equipment deployed for the geophysical survey included a pole-mounted interferometric swath transducer, chirp system with flotation pontoons attached, and sidescan sonar towfish .............................. 3

4. Bathymetry of study area from swath data collected during the survey, with 2-meter contour overlay ..........5

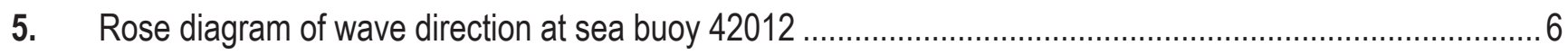

6. Chirp profile showing sea floor morphology and subsurface stratigraphy .................................................

7. Isopach map of surface sediments show shoal systems extending northwest-southeast across study area surrounded by a thin sand sheet.................................................................................................

8. Isopach map of transgressive marine sediments deposited during the early Holocene sea-level rise. .........9

9. Example chirp profile shows variable thickness within the early Holocene transgressive sediments as they infill older fluvial channels.

10. Depth to base of Lower Pleistocene distributary system shows the channel occupies the eastern portion of the study area

11. Raw profile, seismic/core interpretation, and enlarged portion of shoal area provide an example of the various types of deposits within the study area, including the Pleistocene distributary systems, the transgressive-fill deposits, and the overlying late Holocene surface shoals and sandsheets.

12. Depth to base of the Upper Pleistocene distributary system shows a relatively flat surface throughout most of the study area, forming a channel in the westernmost portion

13. Example profile at the northern end of the Pleistocene distributary system showing high-angle seismic reflections in the subsurface.

14. Significant features identified in this study include shoals and fluvial deposits.

15. Seismic profile with sediment core overlay showing the extent of the mud unit at the base of the shoals .. 14

16. Isopach map of the sandy fill deposit shown in figures 11 and 15

17. Conceptual model of the geologic development of the study area. 16

\section{Tables}

1. Physical characteristics of features identified in the study, the study area, and neighboring Petit Bois Island for comparison......

2. Estimated sand volumes within the three main shoals, adjusted to exclude the mud layer at the base of the shoals. 


\section{Conversion Factors}

SI to Inch/Pound

\begin{tabular}{|c|c|c|}
\hline Multiply & By & To obtain \\
\hline \multicolumn{3}{|c|}{ Length } \\
\hline millimeter $(\mathrm{mm})$ & 0.03937 & inch (in.) \\
\hline meter $(\mathrm{m})$ & 3.281 & foot $(\mathrm{ft})$ \\
\hline kilometer (km) & 0.6214 & mile (mi) \\
\hline kilometer (km) & 0.5400 & mile, nautical (nmi) \\
\hline meter $(\mathrm{m})$ & 1.094 & yard $(y d)$ \\
\hline \multicolumn{3}{|c|}{ Area } \\
\hline square kilometer $\left(\mathrm{km}^{2}\right)$ & 0.3861022 & square mile $\left(\mathrm{m}^{2}\right)$ \\
\hline square centimeter $\left(\mathrm{cm}^{2}\right)$ & 0.001076 & square foot $\left(\mathrm{ft}^{2}\right)$ \\
\hline square meter $\left(\mathrm{m}^{2}\right)$ & 10.76 & square foot $\left(\mathrm{ft}^{2}\right)$ \\
\hline square centimeter $\left(\mathrm{cm}^{2}\right)$ & 0.1550 & square inch $\left(\mathrm{ft}^{2}\right)$ \\
\hline \multicolumn{3}{|c|}{ Volume } \\
\hline cubic meter $\left(\mathrm{m}^{3}\right)$ & 264.2 & gallon (gal) \\
\hline cubic meter $\left(\mathrm{m}^{3}\right)$ & 35.31 & cubic foot $\left(\mathrm{ft}^{3}\right)$ \\
\hline cubic meter $\left(\mathrm{m}^{3}\right)$ & 1.308 & cubic yard $\left(\mathrm{yd}^{3}\right)$ \\
\hline
\end{tabular}

Horizontal coordinate information is referenced to the North American Datum of 1983 (NAD 83), Universal Transverse Mercator (UTM) Zone 11 


\section{Near-Surface Stratigraphy and Morphology, Mississippi Inner Shelf, Northern Gulf of Mexico}

By James Flocks, Jack Kindinger, Kyle Kelso, Julie Bernier, Nancy DeWitt, and Michael FitzHarris

\section{Introduction}

Over the past decade, the Mississippi Barrier Islands have been the focus of a comprehensive geologic investigation by the U.S. Geological Survey (USGS), in collaboration with the U.S. Army Corps of Engineers (USACE) and the National Park Service (NPS). The islands (Dauphin, Petite Bois, Horn, East Ship, West Ship, and Cat) are part of the Gulf Islands National Seashore (GUIS), and provide a diverse ecological habitat, protect the mainland from storm waves, and help maintain estuarine conditions within Mississippi Sound (fig. 1). Over the past century, the islands have been in a state of decline with respect to elevation and land-area loss (Morton, 2007). In 2005, the islands were severely impacted by Hurricane Katrina, which inundated them with a storm surge of 8 meters $(\mathrm{m})$ (Fritz and others, 2007), causing severe shoreface erosion and widening breaches in Dauphin, West Ship, and Cat Islands. To evaluate the impact and fate of the islands, understanding their evolution and resiliency became a priority for the USGS under the Northern Gulf of Mexico Ecosystem Change and Hazard Susceptibility Project. The project formed the basis for collaboration with the USACE Mississippi Coastal Improvement Project (MsCIP), which is intended to restore portions of coastal Mississippi and GUIS affected by storm impact. Since then, many studies have contributed to our understanding of the islands' morphology (Otvos and Carter, 2008, Morton and Rogers, 2009, Byrnes and others, 2013; ) and nearshore stratigraphy (Greene and others, 2007; Twichell and others, 2011; Flocks and others, 2011a;

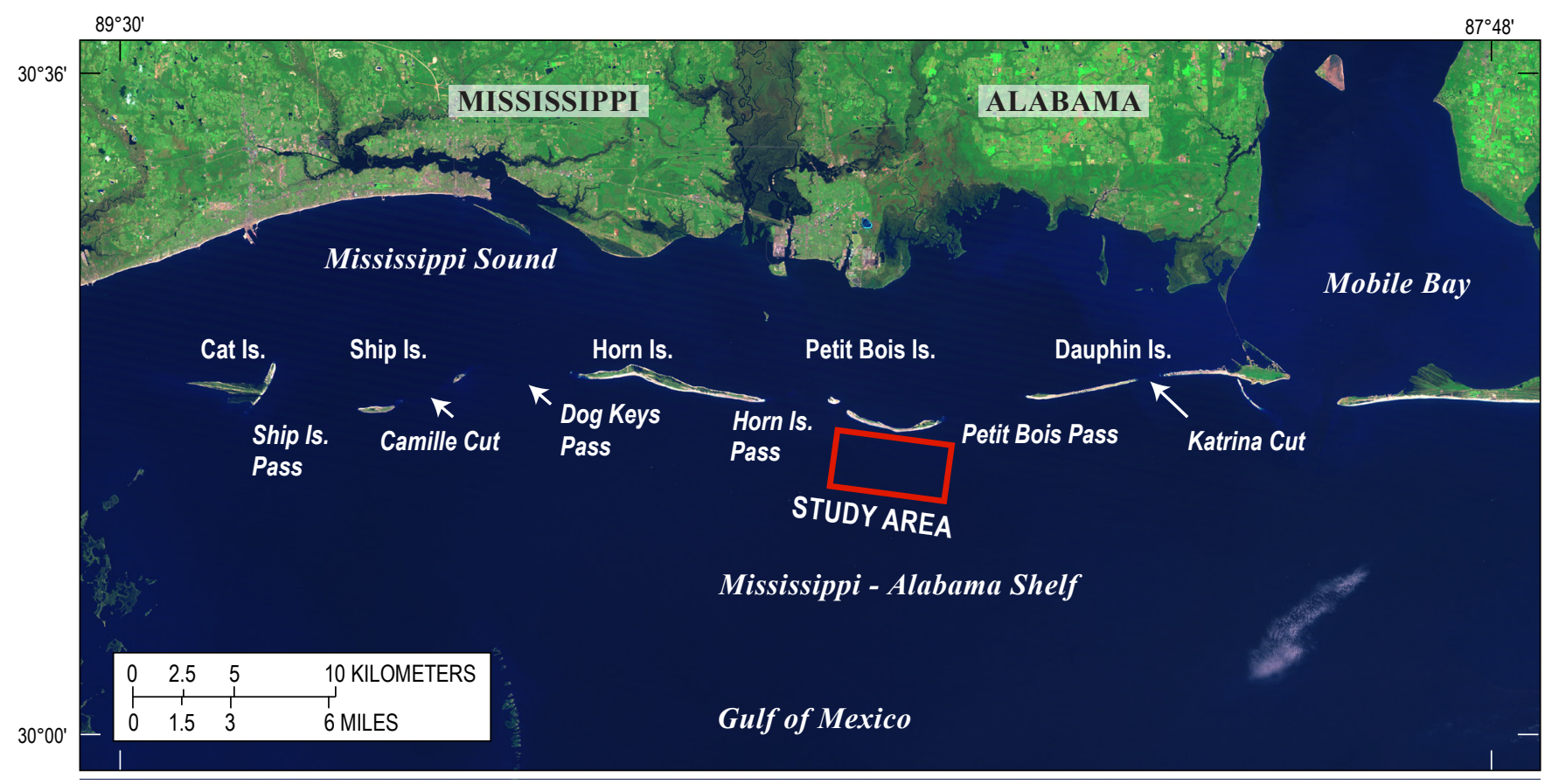

Figure 1. Satellite image showing the islands and inlets of the Gulf Islands National Seashore and surrounding area. Distance is expressed in kilometers (km). 
Buster and Morton, 2011; Kindinger and others, 2014). This report expands upon the nearshore component to provide a stratigraphic and morphologic assessment offshore of Petit Bois Island.

In June 2013, as part of the MsCIP project, the USGS conducted a geophysical survey consisting of about 650 line-kilometers $(\mathrm{km})$, encompassing an area of approximately 212 square kilometers $\left(\mathrm{km}^{2}\right)$. The survey area extended from 1 to $13 \mathrm{~km}$ offshore of Petite Bois Island (fig. 2). The geophysical investigation included interferometric swath bathymetry, sidescan sonar, and chirp subbottom profiling. The intent of the survey was to provide geologic information that would assist the USACE in developing a sediment sampling strategy for identifying deposits suitable for shoreline restoration operations. The data from the geophysical survey would also further our understanding of the geologic framework along the inner shelf. Numerous sea floor and subbottom features were identified. At the surface, shoals and shelf sand sheets of various sizes and orientations are the predominant morphology. In the subsurface, Holocene- and Pleistocene-age features include marine transgressive deposits infilling older fluvial distributary systems. These interpretations from the geophysical research were integrated with sediment cores collected by the USGS and USACE (fig. 2) to provide textural and volumetric information.

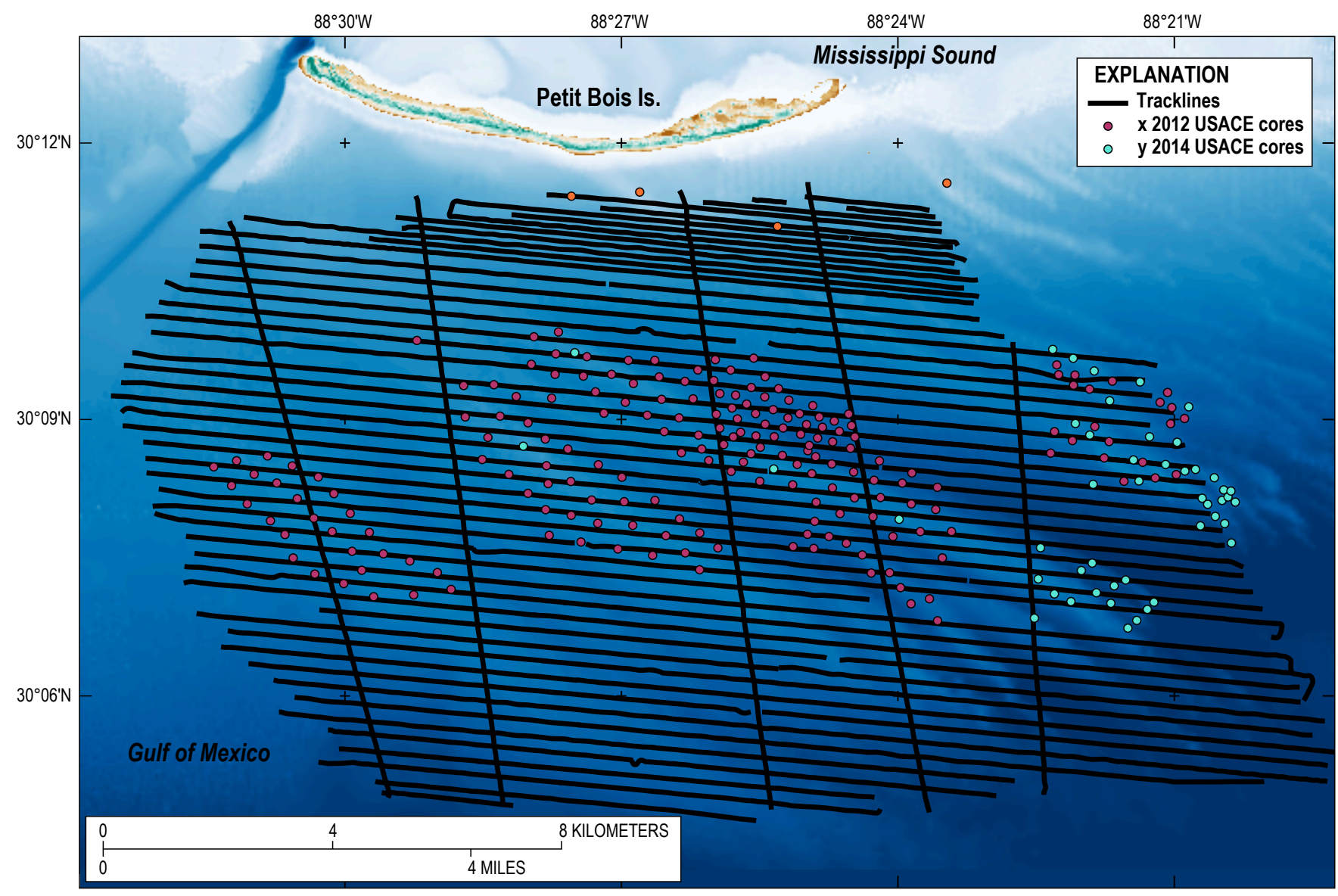

Figure 2. Tracklines (black lines) of the geophysical data collected and locations of sediment cores (colored circles) used in this report. Cores collected by the U.S. Geological Survey in 2010 are represented by orange circles. Cores collected by the U.S. Army Corps of Engineers in 2012 and 2014 are represented by blue and purple circles respectively. Distance is expressed in kilometers (km). Bathymetric image is 2007 DEM, with a 10-meter cell size and referenced to mean high water. Background map courtesy of the NOAA National Geophysical Data Center (NGDC) (http://www.ngdc.noaa.gov/dem/squareCellGrid/download/241). 


\section{Methods}

Approximately $212 \mathrm{~km}^{2}$ of the inner shelf adjacent to Petit Bois Island were surveyed in June 2013 onboard the University of Southern Mississippi research vessel (R/V) Tommy Munro (fig. 3). Line spacing of the tracklines was $150 \mathrm{~m}$ in waters less than $15 \mathrm{~m}$, and $300 \mathrm{~m}$ in deeper waters (fig. 2), oriented parallel to the shoreline. Five shore-perpendicular tracklines were collected across the survey area to tie the horizontal lines together. Three acoustic systems were deployed during the survey:

1. A pole-mounted SEA SWATHplus-H $468 \mathrm{kHz}$ [kilohertz] Interferometric system measured water depth. Navigation and boat motion during the survey was acquired using a Coda Octopus F190 Precision attitude and positioning system, which was differentially corrected by the OmniSTAR HP DGPS [differential global positioning system] constellation. To account for changes in the way water density affected acoustic travel time, sound-velocity at the transducer was continuously recorded. In addition, water column sound-velocity profiles were acquired in a uniform distribution across the study area by bringing the vessel to a stop and recording sound velocity from the sea floor to the surface using a cast profiler.

2. Backscatter imaging of the sea floor was acquired using a Klein 3900 dual frequency (445 and $900 \mathrm{kHz}$ ) side-scan sonar towfish towed off the port quarter of the vessel, approximately $4 \mathrm{~m}$ astern and $2 \mathrm{~m}$ deep. Layback of the towfish to the DGPS antenna was calculated dynamically during acquisition.

3. Subbottom seismic profiles were recorded along the vessel track with an EdgeTech SB-512i chirp towfish towed at the surface off the starboard quarter of the vessel, approximately $5 \mathrm{~m}$ astern. The

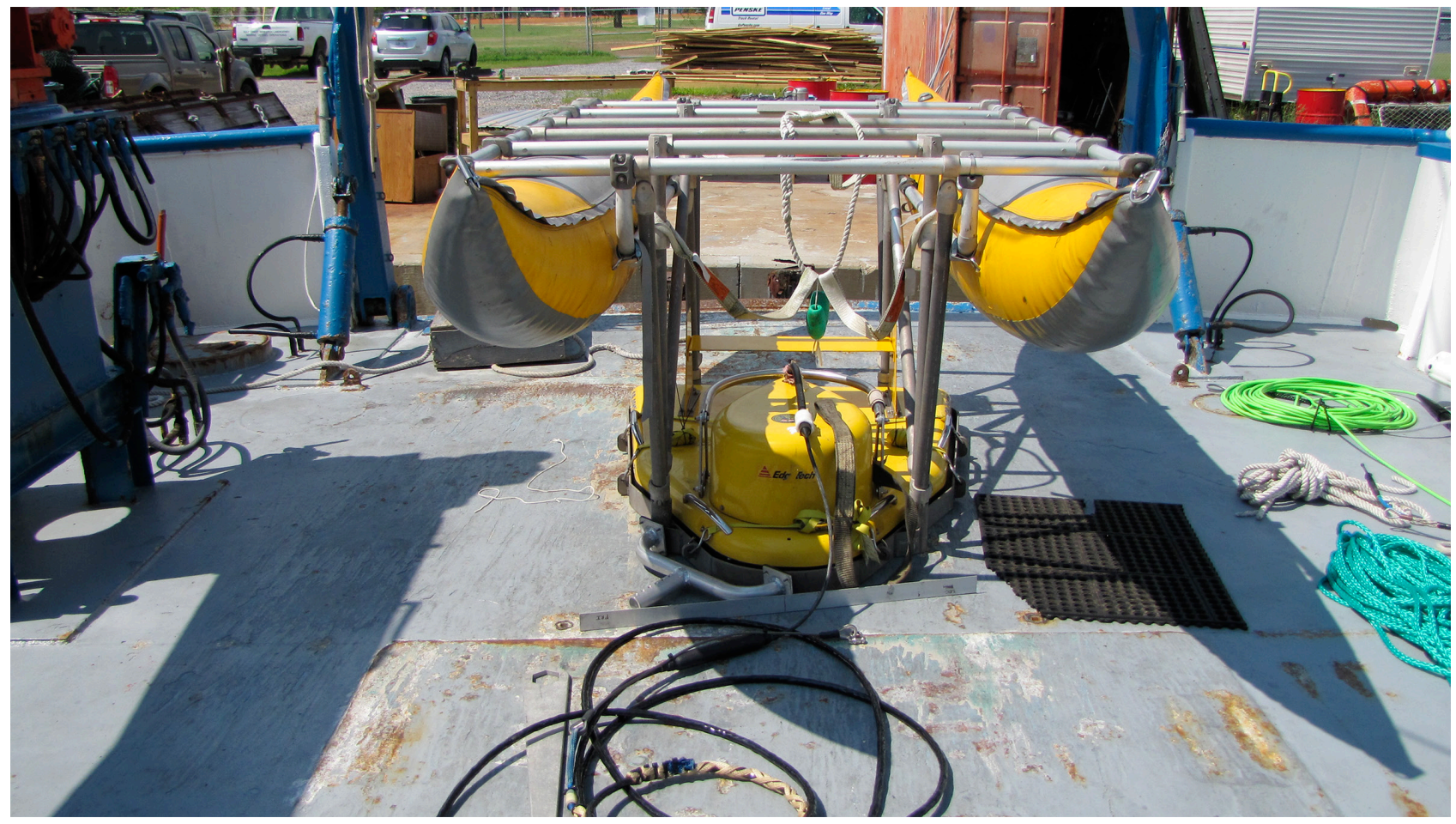

Figure 3. Equipment deployed for the geophysical survey included a pole-mounted interferometric swath transducer, chirp system with flotation pontoons attached (shown above), and sidescan sonar towfish. The survey was conducted on board the research vessel (R/V) Tommy Munro. 
chirp system pulse was $0.5-8 \mathrm{kHz}$, with a $43 \mathrm{kHz}$ sample frequency and a 75 milliseconds (ms) record length. The profiles imaged the top 20-30 m of the subsurface stratigraphy with sub-meter vertical resolution. The subbottom data are reported and archived in a USGS Data Series publication, which is currently in production.

For further detail on data acquisition and processing, see; Pendleton and others, (2010); Forde and others (2011); Pfeiffer and others (2011), and Twichell and others (2011). The geologic interpretations were developed with OpendTect seismic interpretation software, and the maps were created using Generic Mapping Tools (GMT) and Quantum Geographic Information System (QGIS), all of which are open source software applications.

\section{Study Area and Geologic Setting}

The study was conducted on the inner Mississippi-Alabama shelf, a slowly subsiding, passive continental margin bound to the west by the Mississippi River Delta and to the east by the DeSoto Canyon offshore of the Florida Panhandle (Sydow and Roberts, 1994). The shallow stratigraphy of this region is the product of fluvial-marine sedimentation driven by sea-level oscillations during the late Pleistocene and into the Holocene (Flocks and others, 2011b). During periods of lower sea level, the region was a flat, low elevation coastal plain with low gradient rivers meandering across older shelf stratigraphy (Kindinger and others, 1994; Bartek and others, 2004). Within the study area, fluvial systems that extended across the shelf are related to modern watersheds in southern Mississippi and Alabama (for example, the Fowl, Bayou La Batre, Pascagoula, and Pearl rivers). Throughout the Holocene, sea-level rise flooded the coastal plain, infilling the river embayments with sediment and forcing bayhead deltas to migrate upstream (Bart and Anderson, 2004). Burial of these transgressive deposits produced the most complete stratigraphic component of the inner-shelf features. Tidal inlet and barrier island development seaward of the embayments were inundated by rapid sea-level rise and reworked into expansive sand sheets and shoals composed of moderately sorted medium to fine sand (Doyle and Sparks, 1980). West of present day Mobile Bay, shoals are rare and occur almost exclusive to the area between Dauphin and Petite Bois Islands. These shoals are stable features extending from $\sim 4$ to $20 \mathrm{~m}$ water depth. They trend northwest-southeast, parallel to the prevailing wave climate, and are composed of poor to moderately sorted medium sand (Flocks and others, 2011a). By about 5 thousand years before present (5 kyr BP) sea-level rise reached the position of GUIS, and a dominant westward littoral system initiated the development of the barrier islands. Sediment supply for the islands was sourced primarily from the Mobile River embayment deposits (Otvos, 1981; Greene and others, 2007). As sea level reached its present position, the St. Bernard Delta complex of the Mississippi River Delta encroached into the western Mississippi-Alabama Shelf, covering the backfilled stratigraphy with muddy prodelta deposits until delta development ceased about 2 kyr BP (Otvos and Giardino, 2005), completing the modern morphologic setting of the inner shelf.

\section{Study Results}

\section{Bathymetry}

The sea floor within the study area slopes gently to the southeast (fig. 4). In general, sea floor gradients across the study area are about 0.03 degrees $\left(^{\circ}\right)$. This gradient is consistent with most of the Mississippi-Alabama Shelf within $20 \mathrm{~m}$ water depth, which typically has a gradient of less than $1^{\circ}$ (Flocks 
and others, 2011b). A series of four northwest-southeast trending shoals span the study area (fig. 4). The orientations of the shoals vary from $121^{\circ}$ to $131^{\circ}$, from north. Wave data measurements from the closest buoy (located $83 \mathrm{~km}$ east-southeast of the study area) indicate that shoal direction is oriented parallel to the prevailing wave climate (fig. 5). A similar investigation immediately east of the study area (Flocks and others, 2011a) suggests that shoals in this area are vestiges of the marine environment prior to the present sea-level highstand and are no longer active. The prevailing regional wave climate was likely the same throughout the late Holocene, and wave action at lower sea levels influenced shoal orientation, similar to other shoal systems across the mid-shelf (such as the Perdido Shoals; McBride and others, 1999).

In the profiles, the shoals are the predominant features on an otherwise flat inner shelf (fig. 6), which is covered by a thin $(<1.5 \mathrm{~m})$ sand sheet that grades laterally into muds within the intershoal areas (Flocks and others, 2010). Individually the shoals vary in width, length, and thickness (fig. 7). The three largest shoals within the study area range in width from $0.7 \mathrm{~km}$ at their southeastern extents to over $1.5 \mathrm{~km}$ at their northwestern ends, with lengths ranging from 7 to $9 \mathrm{~km}$. Their maximum thickness is similar, at about $4 \mathrm{~m}$, although shoal 1 has consistently higher elevations, providing 18 percent

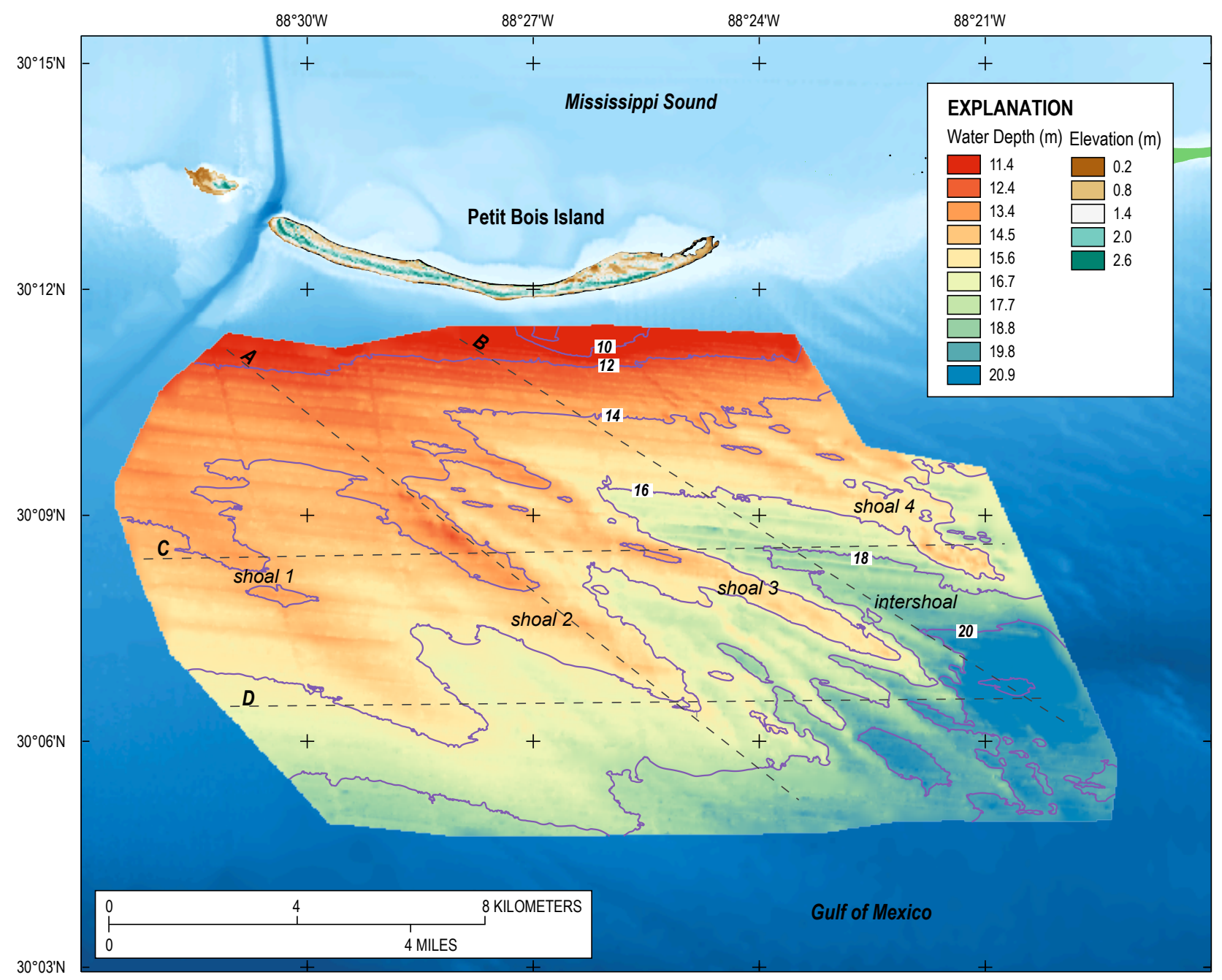

Figure 4. Bathymetry of study area from swath data collected during the survey, with 2-meter $(\mathrm{m})$ contour overlay. Shoal features discussed in the report are labeled. Lidar-derived topography of Petit Bois Island from Bonisteel-Cormier and others (2010). Distance is expressed in kilometers $(\mathrm{km})$. Bathymetric image is 2007 DEM, with a 10-meter cell size and referenced to mean high water. Background map courtesy of the NOAA National Geophysical Data Center (NGDC) (http://www.ngdc.noaa.gov/dem/squareCellGrid/download/241). 


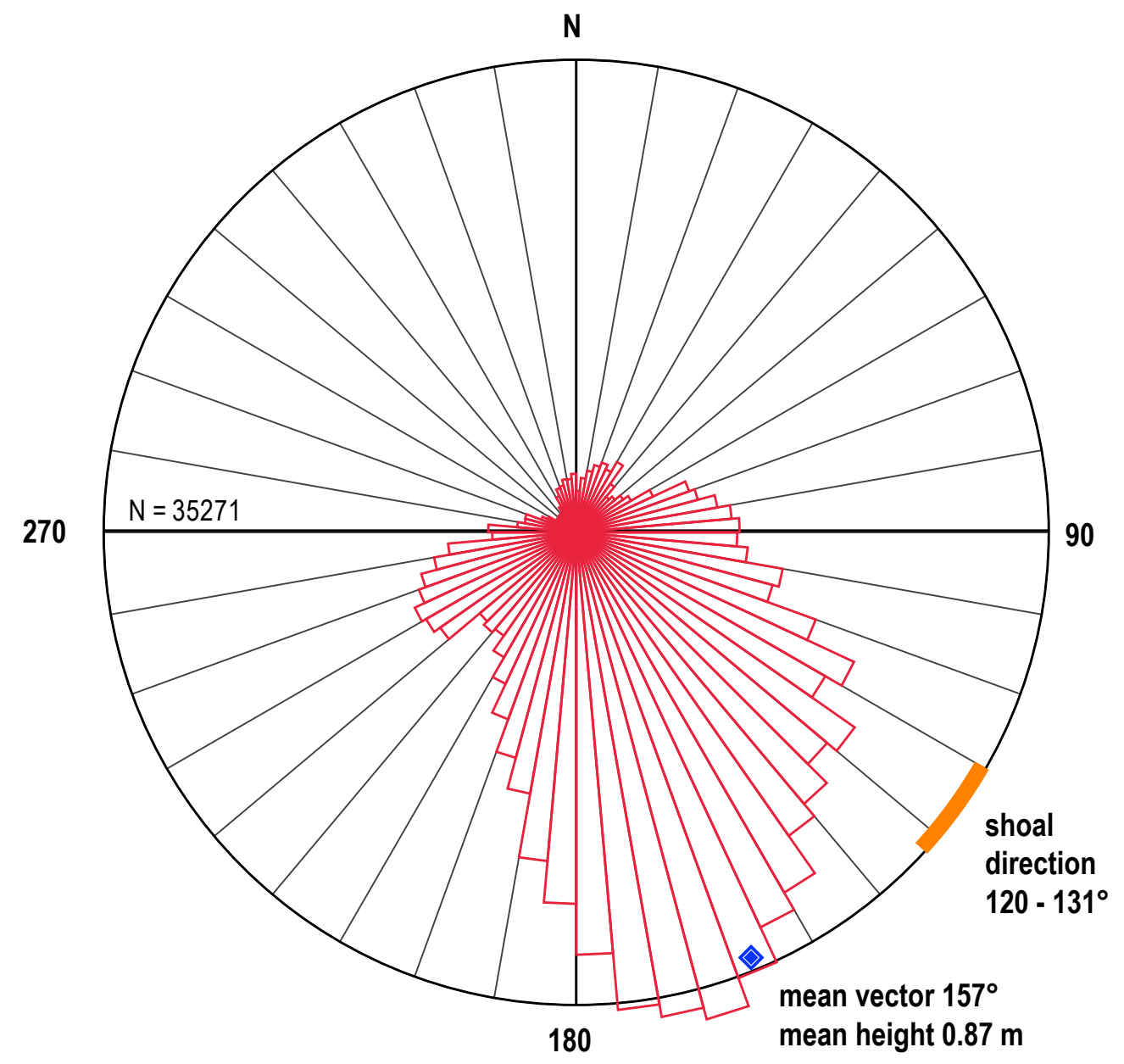

Figure 5. Rose diagram of wave direction at sea buoy 42012 (located 83 kilometers east-southeast of the study area) between the years 2009 and 2013. Range of shoal axis orientation for the three shoals is shown. Mean height is expressed in meters (m).

more volume per unit area (table 1). The shoal contains 71 percent more volume per unit area than that of the sheet sands within the intershoal area. The combined volume of the three largest shoals comprise 15 percent of the surface sediments within the study area and contain 24 percent more sediment than the subaerial portion of neighboring Petit Bois Island (table 1).

Visual observations of the sediment cores acquired within the shoals describe consistent, poorly graded sand with silt and few shell fragments (USACE, 2014). Grain size and sand content within the deposits is variable, with a D50 ranging from 0.11 to 0.34 millimeters (mm) (very-fine sand to medium sand), and 81 to 99 percent sand (table 1). The intershoal areas typically contain less than $1 \mathrm{~m}$ of fine sand (D50: 0.17 to $0.32 \mathrm{~mm}$ ) variable amounts of silt, and sand content ranging from 65 to 99 percent. D50 refers to the median diameter particle size, where 50 percent of the sample is larger and 50 percent is smaller than the median grain size.

\section{Stratigraphy}

The base of the shoal/intershoal system lies conformably on a thin layer of transgressive marine sediments deposited during the initial Holocene sea-level rise. These sediments are composed of poorly sorted fine sand and silt, and sand content ranges from 89 to 92 percent (USACE, 2014). In the 


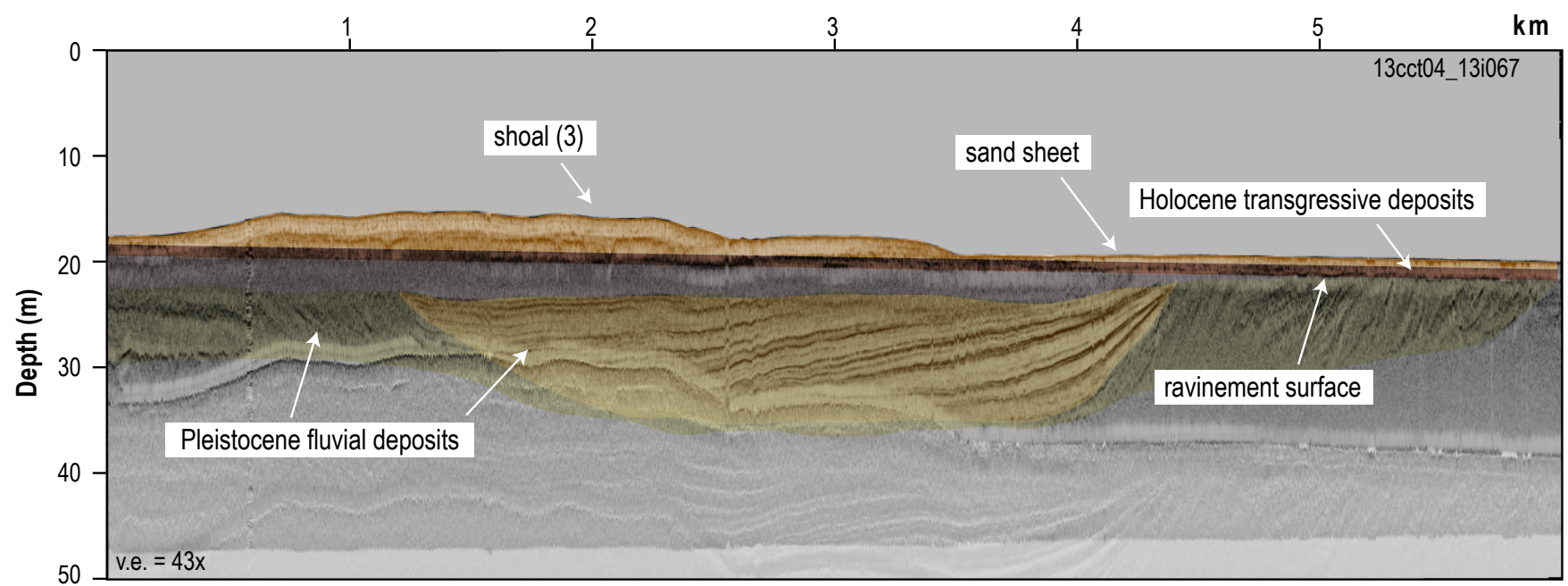

Figure 6. Chirp profile showing sea floor morphology and subsurface stratigraphy. At depth, remnants of lowstand Pleistocene distributary systems are truncated by a ravinement surface and overlain by reworked fluvial/marine sediments deposited during sea-level rise. The morphology of the sea floor includes a thin sand sheet and a series of shoals that extends across the study area. Location of the profile is shown in figure 7. Depth is expressed in meters $(\mathrm{m})$; distance is expressed in kilometers $(\mathrm{km})$. Vertical exaggeration (v.e.) is 43 times.

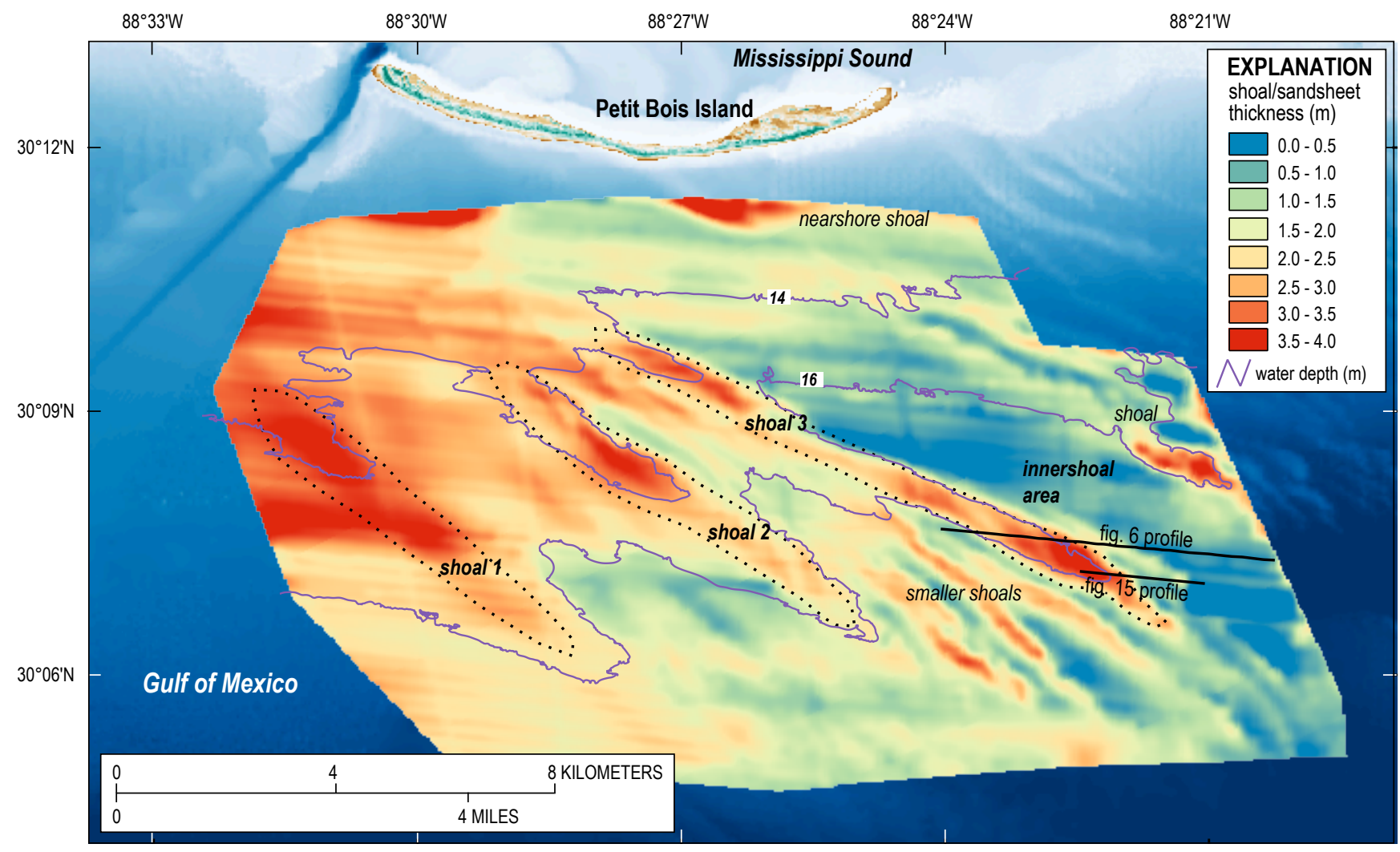

Figure 7. Isopach map of surface sediments show shoal systems extending northwest-southeast across study area surrounded by a thin $(<1.5$ meter $(\mathrm{m}))$ sand sheet. Base of surface sediments is defined by the top of the Holocene transgressive deposits shown in figure 6 . Distance is expressed in kilometers $(\mathrm{km})$. Bathymetric image is $2007 \mathrm{DEM}$, with a 10-meter cell size and referenced to mean high water. Background map courtesy of the NOAA National Geophysical Data Center (NGDC) (http://www.ngdc.noaa.gov/dem/squareCellGrid/download/241). 
Table 1. Physical characteristics of features identified in the study, the study area, and neighboring Petit Bois Island for comparison.

\begin{tabular}{|c|c|c|c|c|c|c|c|c|}
\hline Deposit & $\mathrm{km}^{2}$ & $\begin{array}{l}\text { Volume } \\
\times 10^{6} \mathrm{~m}^{3}\end{array}$ & $\begin{array}{c}\text { Minimum } \\
\text { thickness } \\
\text { m }\end{array}$ & $\begin{array}{c}\text { Maximum } \\
\text { thickness } \\
\text { m }\end{array}$ & $\begin{array}{l}\text { Volume Per } \\
\text { unit area } \\
\times 10^{6} \mathrm{~m}^{3} / \mathrm{km}^{2}\end{array}$ & $\begin{array}{c}\text { Overburden } \\
\text { thickness } \\
\text { m }\end{array}$ & $\mathrm{mm}$ & $\begin{array}{c}\text { Sand } \\
\text { content }^{4} \\
\%\end{array}$ \\
\hline Shoal 01 & 7.1 & 24.2 & 2.5 & 4 & 3.4 & 0 & $0.11-0.25$ & $81-98$ \\
\hline Shoal 02 & 7.2 & 20.3 & 2.1 & 3.8 & 2.83 & 0 & $0.13-0.32$ & $84-99$ \\
\hline Shoal 03 & 7.6 & 21.7 & 1.4 & 4 & 2.84 & 0 & $0.19-0.34$ & $84-99$ \\
\hline ISS $^{1}$ & 15 & 14.5 & 0 & 1.5 & 0.96 & 0 & $0.17-0.32$ & $65-99$ \\
\hline Sandy fill & 19.7 & 83.5 & 1 & 6.8 & 4.23 & $2-9$ & $0.18-0.24$ & $83-97$ \\
\hline Bayhead delta ${ }^{2}$ & 12.6 & 100.4 & 4 & 11 & 7.94 & $3-6$ & 0.28 & 91 \\
\hline Study area ${ }^{3}$ & 198.4 & 431 & 0 & 5.8 & 2.17 & 0 & $0.19-0.51$ & $80-99$ \\
\hline Petit Bois Is. ${ }^{3}$ & 4 & 5.3 & 0 & 5.3 & 1.33 & 0 & 0.36 & 99 \\
\hline
\end{tabular}

${ }^{1}$ Intershoal sand sheet, area east of shoal 3 (fig. 7). ${ }^{2}$ Portion within study area. ${ }^{3}$ Surface deposits only. ${ }^{4}$ Grainsize analysis from (USACE, 2014). Bayhead delta grainsize analysis from Kelso and Flocks (2015).

eastern half of the study area, the deposits are typically less than $2 \mathrm{~m}$ thick and uniform (figs. 6 and 8). To the west they thicken considerably, up to $4 \mathrm{~m}$ as they infill former fluvial channels that crossed the area during the last lowstand (figs. 8 and 9). The thicker deposits delineate a channel trending north to south across the central part of the study area and a larger channel that occupies the western portion of the study area (fig. 8). This channel is one of two large Pleistocene distributary systems located at either end of the study area (figs. 6 and 9). Figure 10 outlines the oldest and largest channel. The channel ranges from 2.5-6.5 km in width and contains various patterns of fill (figs. 6 and 11). Sediment cores penetrated the shallowest deposits within the channel fill and found 83 to 97 percent fine sand (table 1). This deposit has a distinct acoustic pattern (see sandy fill, fig. 11) and can be mapped out relative to the channel (fig. 10). The feature is up to $6.8 \mathrm{~m}$ thick and comparable in volume to the large shoals, with $1.97 \times 10^{7}$ cubic meters $\left(\mathrm{m}^{3}\right)$ of sediment (table 1$)$.

The base of the older Pleistocene channel described above is incised to the west by the other large Pleistocene channel (fig. 9). This horizon is fairly uniform in depth elsewhere in the study area (fig. 12), dipping slightly to the south and southeast. The stratigraphic position of the channel indicates that it represents a more recent sea-level cycle than the older channel, possibly the last lowstand (oxygen isotope stage 2) as it contains the early Holocene transgressive deposits described earlier (fig. 9). The distributary system is not as large as the older channel, although it extends out of the study area to the west so its total size is not resolved in this study. Sediment cores within this deposit indicate that it contains mud at the base, grading into 90 percent fine sand at the top (USACE, 2014).

In the northeastern portion of the study area, the Pleistocene fluvial deposits terminate at a distinct sequence of high-angle reflections in the seismic record (fig. 13) that could represent bayhead delta deposits stranded within the former fluvial channel. Reflectors dipping to the north, south, and west define the deposit, with patterns consistent to similar bayhead delta deposits identified in the Mobile-Tensaw paleo-valley (Greene and others, 2007). The eastern side of the deposit extends beyond the study area. A sediment core that penetrated this deposit found 91 percent moderately sorted fine to medium sands increasing downcore (Kelso and Flocks, 2015), interbedded with lenticular silts (table 1). The thickness of the feature and its position relative to the fluvial channel are shown in figure 10. The deposit is lens-shaped, with a maximum thickness of $11 \mathrm{~m}$ and a volume within the study area of $10 \times 10^{7} \mathrm{~m}^{3}$, a very large feature compared to the other deposits characterized in this study (table 1). 


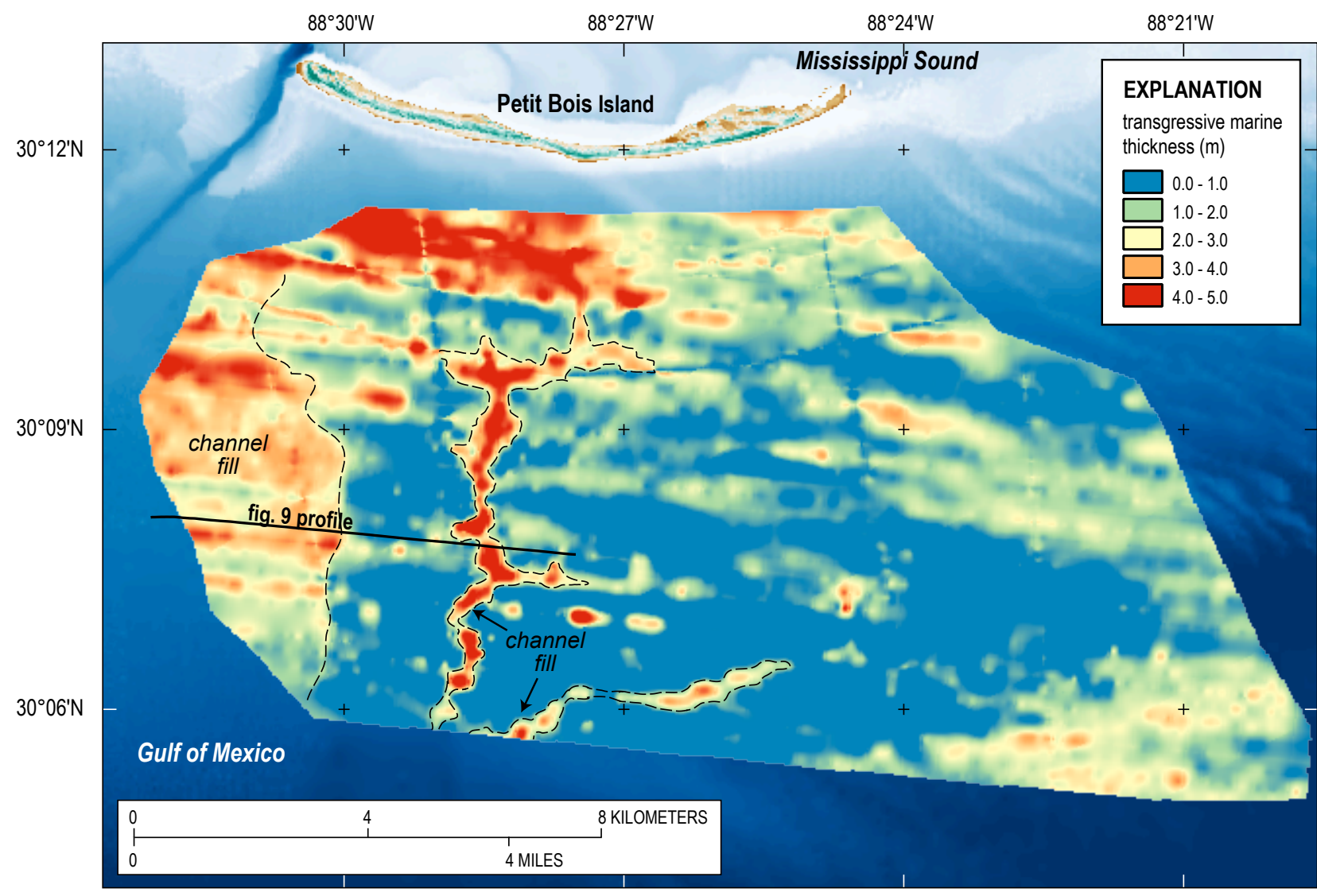

Figure 8. Isopach map of transgressive marine sediments deposited during the early Holocene sea-level rise. Examples are shown in profile in figures 6 and 9 . Sediment thickness is thin except where deposits infill channels. Thickness is expressed in meters (m); distance is expressed in kilometers $(\mathrm{km})$. Bathymetric image is $2007 \mathrm{DEM}$, with a 10-meter cell size and referenced to mean high water. Background map courtesy of the NOAA National Geophysical Data Center (NGDC) (http://www.ngdc.noaa.gov/dem/squareCellGrid/download/241).

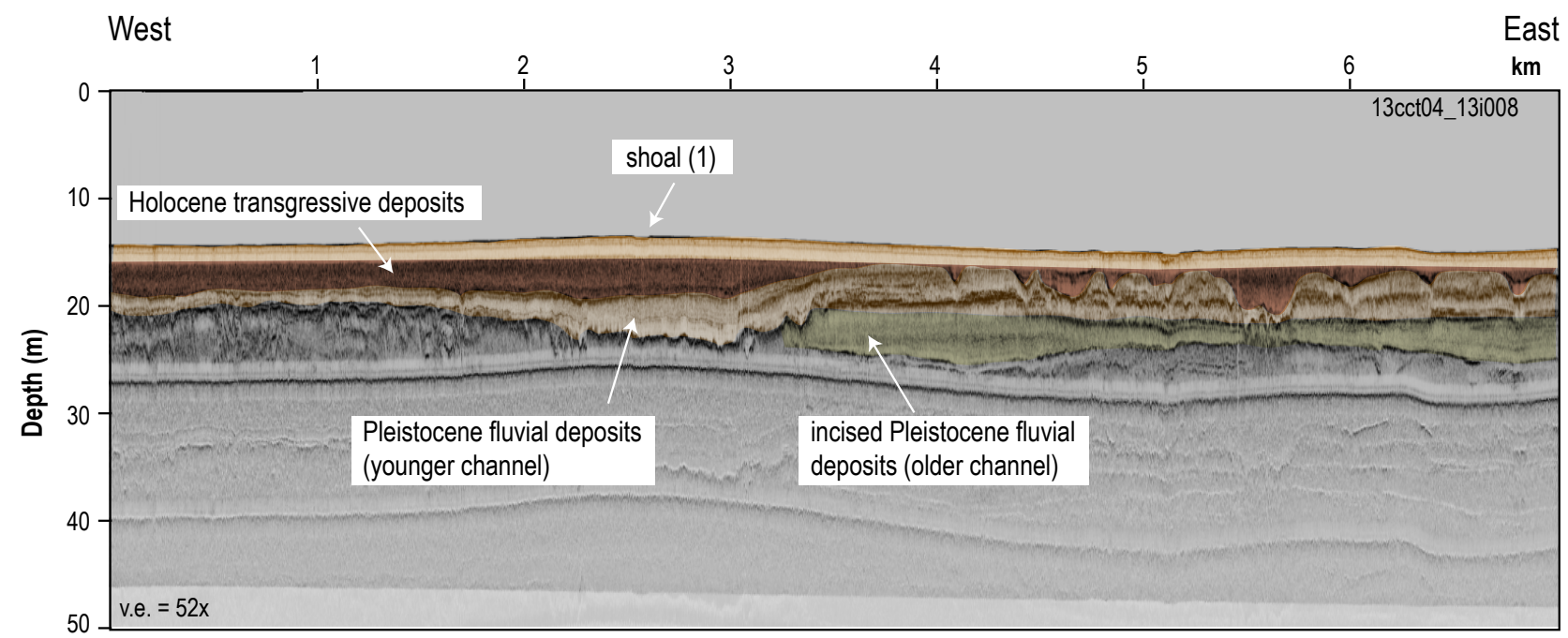

Figure 9. Example chirp profile shows variable thickness within the early Holocene transgressive sediments as they infill older fluvial channels. At depth, the profile shows younger Pleistocene channel deposits incising older channel stratigraphy. Profile location shown in figure 8. Depth is expressed in meters $(\mathrm{m})$; distance is expressed in kilometers $(\mathrm{km})$. 


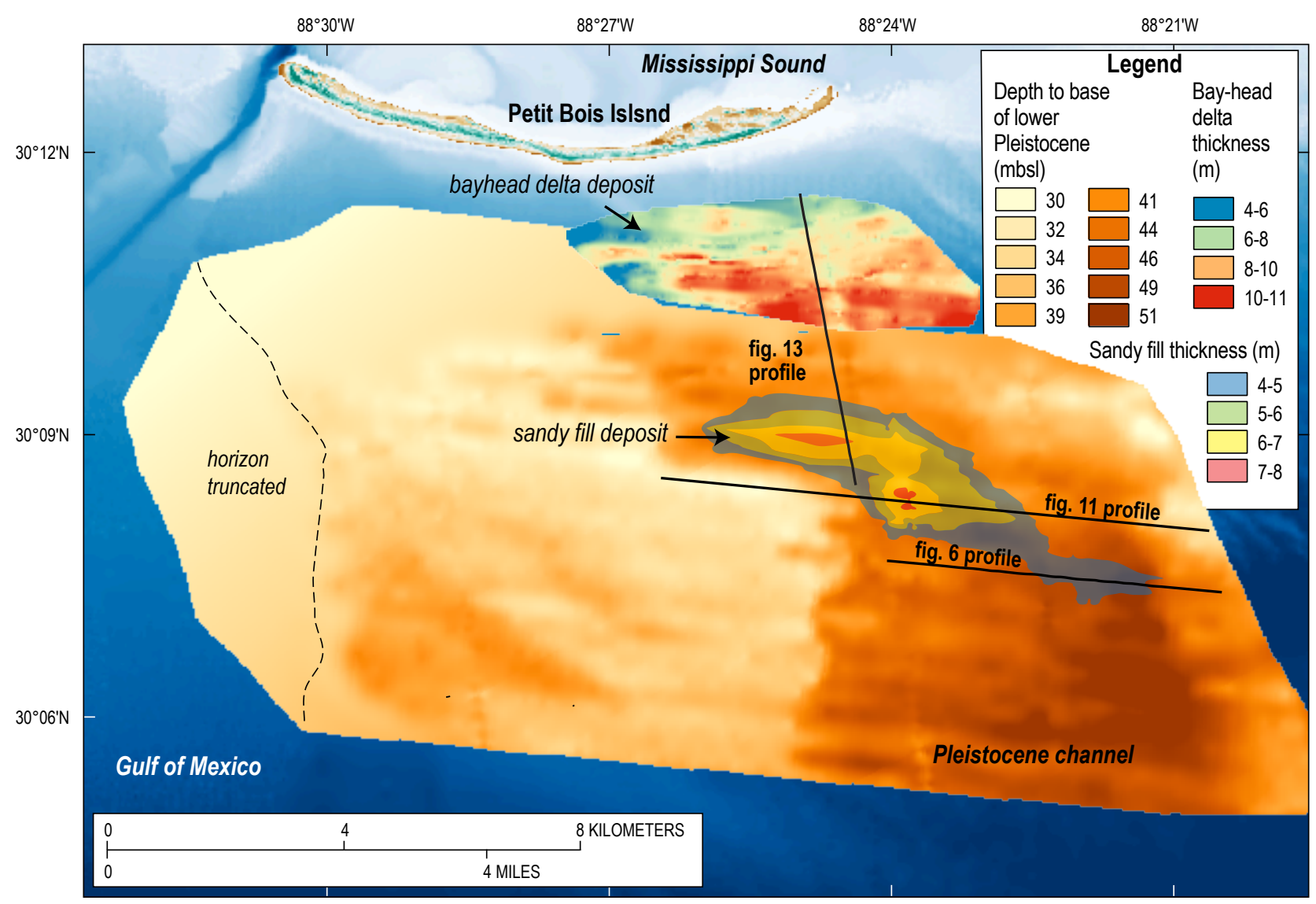

Figure 10. Depth (meters below sea level, $(\mathrm{mbsl})$ ) to base of Lower (older) Pleistocene distributary system shows the channel occupies the eastern portion of the study area. Example profiles of the channel are shown in figures 6 and 11. The western end of the horizon is incised by a younger distributary system (see fig. 9 for example). The distributary system contains several distinct patterns of fill. Sediment cores collected in the shallow fill show fine to medium grain sand. The isopach and location of this feature are inset (sandy fill), and an example profile of the deposit is shown in figures 6 and 11. At the northern end of the Pleistocene distributary system, seismic patterns consistent with bayhead delta deposits are mapped out as an isopach inset; an example profile of the deposit is shown in figure 13. Thicknesses are expressed in meters (m); distance is expressed in kilometers $(\mathrm{km})$. Bathymetric image is 2007 DEM, with a 10-meter cell size and referenced to mean high water. Background map courtesy of the NOAA National Geophysical Data Center (NGDC) (http://www.ngdc.noaa.gov/dem/squareCellGrid/download/241).

\section{Discussion}

The features identified in the study represent Pleistocene fluvial stratigraphy overlain by Holocene deposits that include transgressive marine sediments, sand sheets, and shoals. These Holocene deposits were reworked from the Lower Pleistocene units during sea-level rise. The prevailing wave climate shaped the shoals prior to present sea-level conditions. The position of the shoals relative to the fluvial channels suggests they were sourced locally rather than from regional littoral processes. Their genesis is different from the processes that created the present day barrier islands, which were formed through longshore transport of sediment from deposits at the mouth of Mobile Bay (Morton, 2007). While the GUIS barrier islands are actively migrating in response to wave climate and storms (Morton, 2007; Otvos and Carter, 2008; Byrnes and others, 2013), bathymetric change analysis of shoal systems east of the study area suggests relative offshore shoal stability over the past century (Twichell and others, 2011; Flocks and others, 2011a) and likely since sea-level rise approached present levels around 4-6 ky BP. The intershoal areas are composed predominantly of a thin $(<1 \mathrm{~m})$ layer of muddy sand. 

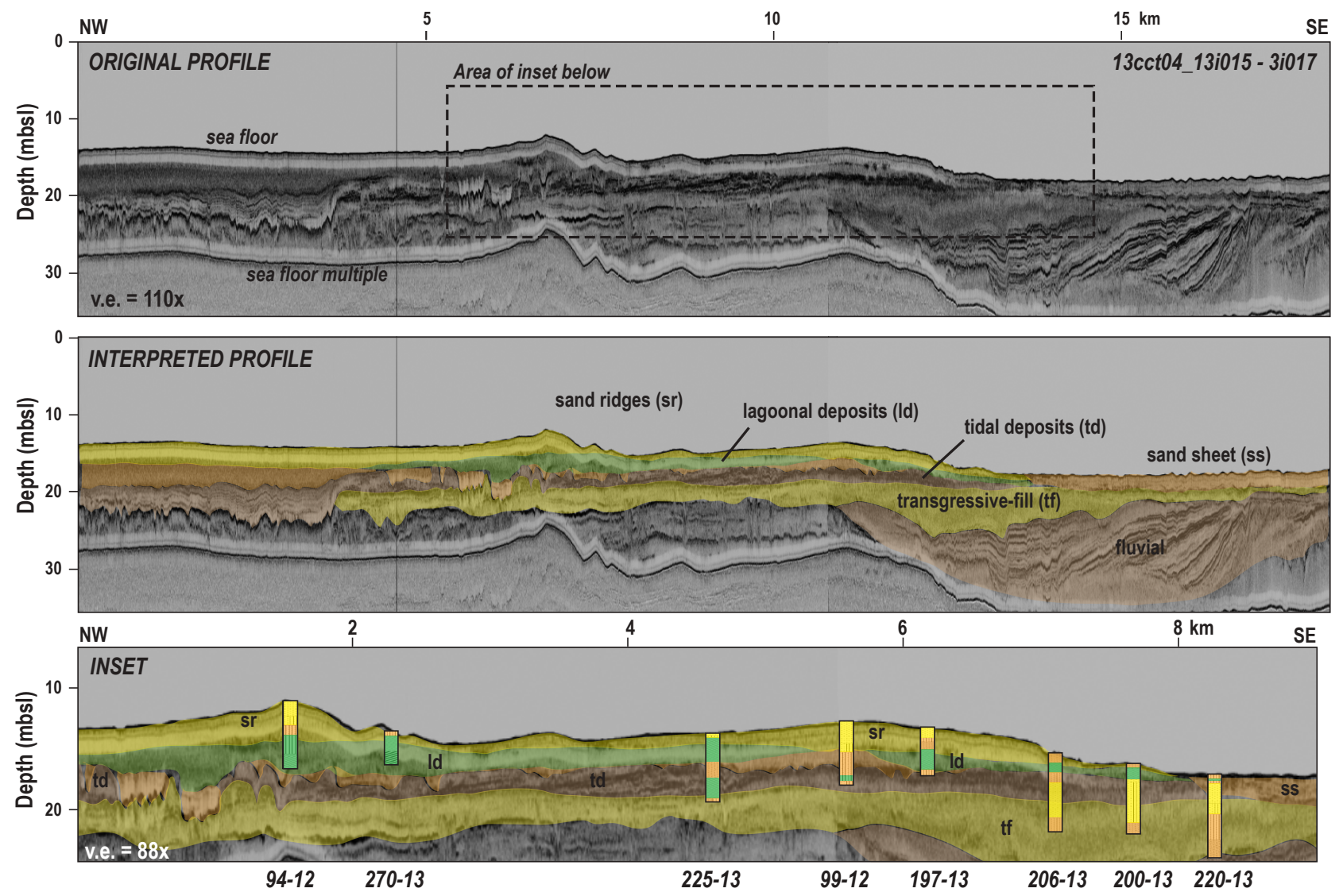

Figure 11. Raw profile (top), seismic/core interpretation (center), and enlarged portion of shoal area (bottom) provide an example of the various types of deposits within the study area, including the Pleistocene distributary systems, the transgressive-fill deposits, and the overlying late Holocene surface shoals and sandsheets. Location of profile shown in figure 10, as is the location and isopach of "sandy fill" deposit (tf). This feature was penetrated by sediment cores and found to contain medium-grained sand. Depth is expressed in meters below sea level (mbsl); distance is expressed in kilometers $(\mathrm{km})$. Vertical exaggeration is $88 \mathrm{x}$.

The stratigraphy below the surface deposits is primarily fluvial systems formed during past sealevel lowstands. Seismic reflection geometries within the fluvial channels reveal that different types of sedimentary patterns (figs. 6 and 11) were deposited under changing physical conditions during sea-level oscillations. Cores that penetrate the uppermost units of channel fill reveal poorly sorted, fine-grained sand. Small amounts of shell material within these deposits suggest transgressive back-filling of the distributary system during sea-level rise. At the northern end of the older Pleistocene channel, high-angle seismic reflection patterns (fig. 13) suggest bayhead delta sediments were captured within the former incised valley during sea-level rise.

\section{Sand Resources}

Sea floor and subsurface deposits that could provide sediment resources for restoration projects include the shoals and Pleistocene channel fill (fig. 14). Several large shoals cross the study area and contain up to $3.5 \mathrm{~m}$ of sediment with sand content that ranges from 81 to 99 percent. However, the base of the shoals contains a mud layer described in (USACE, 2014) as silts and clays with trace fine-grained sand (fig. 15). This mud layer is persistent throughout the study area and reduces the total sand content of the shoals (table 2). 


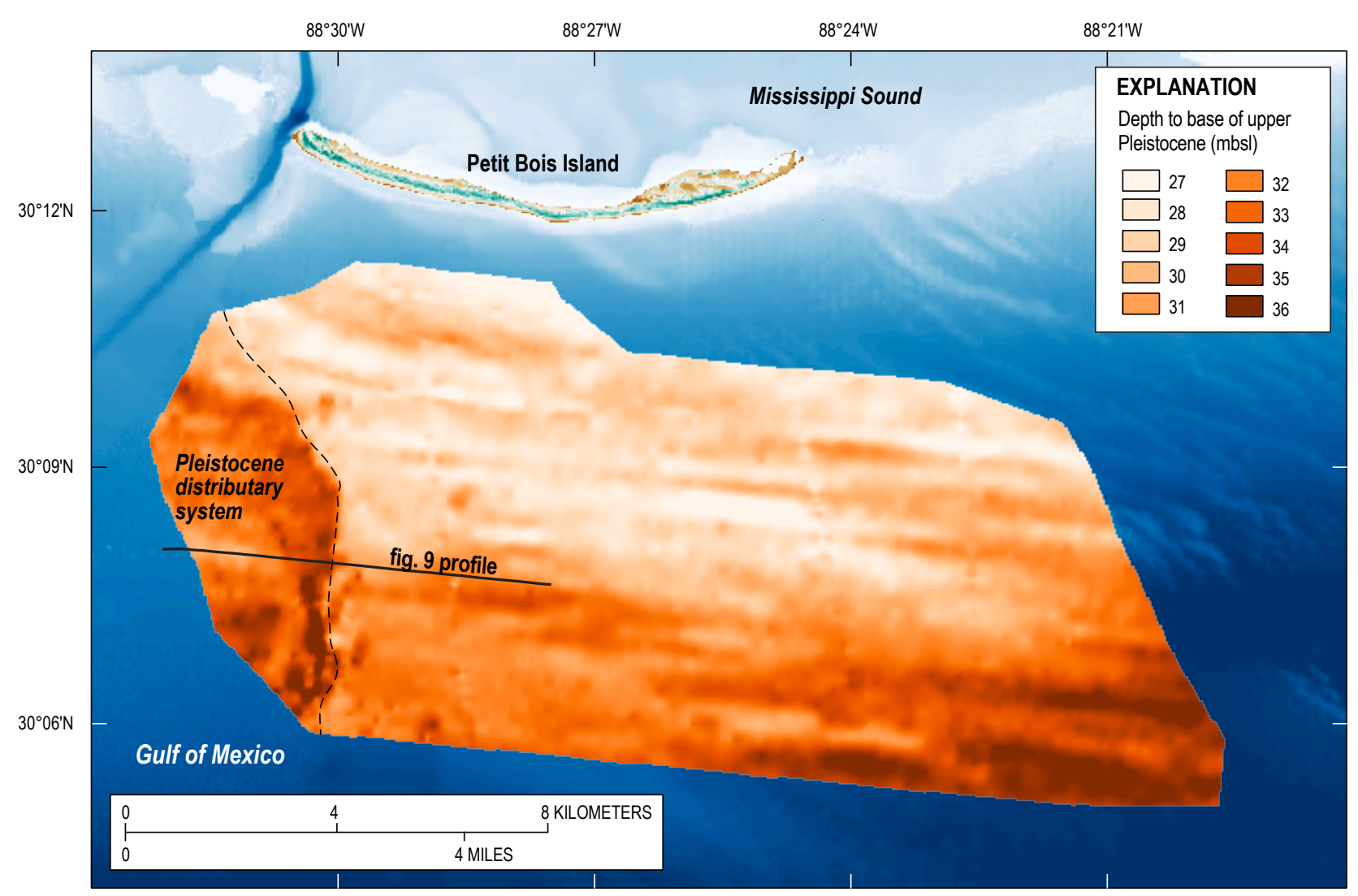

Figure 12. Depth to base of the Upper (younger) Pleistocene distributary system (meters below sea level (mbsl)), shows a relatively flat surface throughout most of the study area (dipping to the southeast), forming a channel in the westernmost portion. An example profile of the channel deposits is shown in figure 9. Distance is expressed in kilometers $(\mathrm{km})$. Bathymetric image is $2007 \mathrm{DEM}$, with a 10-meter cell size and referenced to mean high water. Background map courtesy of the NOAA National Geophysical Data Center (NGDC) (http://www.ngdc. noaa.gov/dem/squareCellGrid/download/241).

Subsurface features that potentially contain suitable amounts of sandy material are the transgressive channel-fill (figs. 11, 13, and 15), and bayhead delta deposits (fig. 13). Their physical characteristics are shown in table 1 and their spatial extent in figures 10, 14, and 16. The fill deposit is composed of 83 to 97 percent fine sand (USACE, 2014), which would yield about $75 \times 10^{6} \mathrm{~m}^{3}$ of sand, although the entire deposit is too deep to excavate. Figure 15 demonstrates that, as a resource, access to the buried deposit would be more productive through the intershoal areas, where the muddy unit found at the base of the shoals is not present. Figure 16 is a map of the overburden, which includes the shoals, sand sheet, and the transgressive unit, relative to the sandy fill deposit. Figure 14 displays outlined areas where the muddy unit that underlies the shoals can be avoided to maximize sand content.

The other deposit within the Pleistocene fluvial channel is located at the northern end of the study area, adjacent to Petit Bois Island (figs. 10 and 14), and is interpreted to be bayhead delta deposits (fig. 13). With up to $11 \mathrm{~m}$ of 91 percent fine to medium sand, this deposit would yield the highest volume of sand within the study area $\left(91 \times 10^{6} \mathrm{~m}^{3}\right)$, although the sand content is variable down section, and it is unlikely the entire resource could be recovered. The deposit is overlain by $2-5 \mathrm{~m}$ of sandy mud. As a borrow site, the location is $1-4 \mathrm{~km}$ from Petite Bois Island, and reduction of sea floor elevation at this location could affect wave dynamics at the island. Modeling of oceanographic conditions would be necessary to determine how removal of this material would impact the island shoreface. 
West

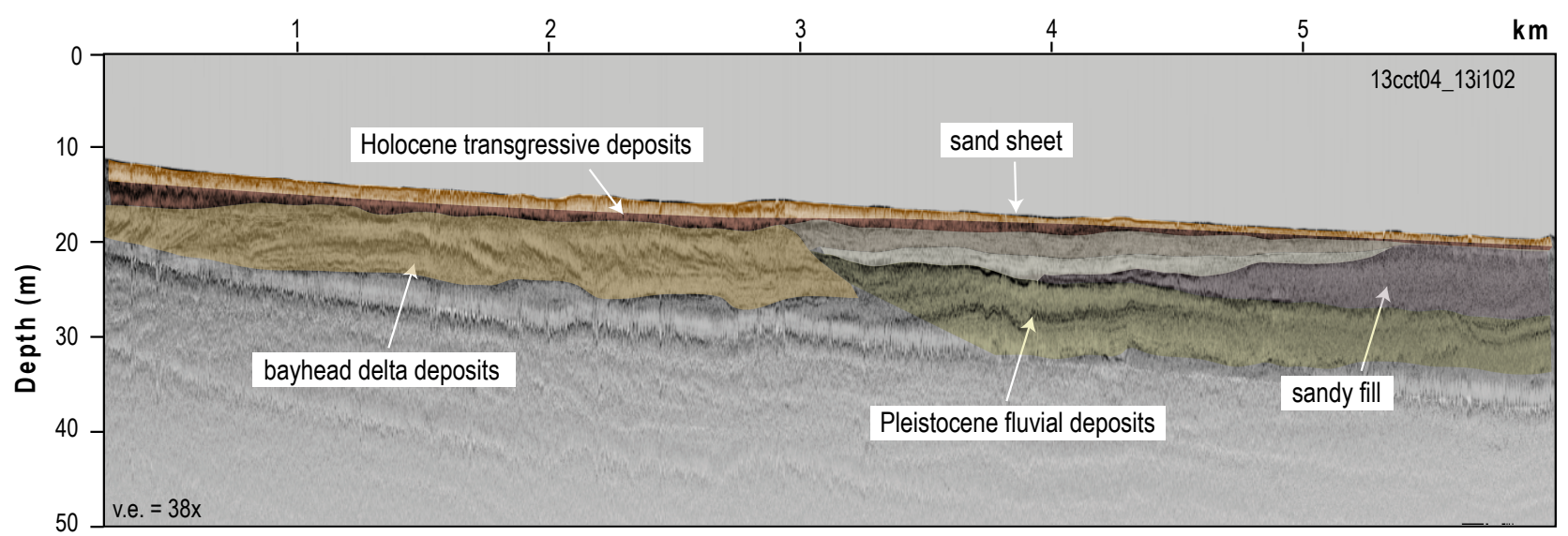

Figure 13. Example profile at the northern end of the Pleistocene distributary system (see fig.10 for location) showing high-angle seismic reflections in the subsurface. The position and pattern of the feature suggest that it represents bayhead delta deposits stranded during a former sea-level rise. Location and thickness of the deposit are shown in figure 10. Depth is expressed in meters $(\mathrm{m})$; distance is expressed in kilometers $(\mathrm{km})$. Vertical exaggeration is $38 \mathrm{x}$.

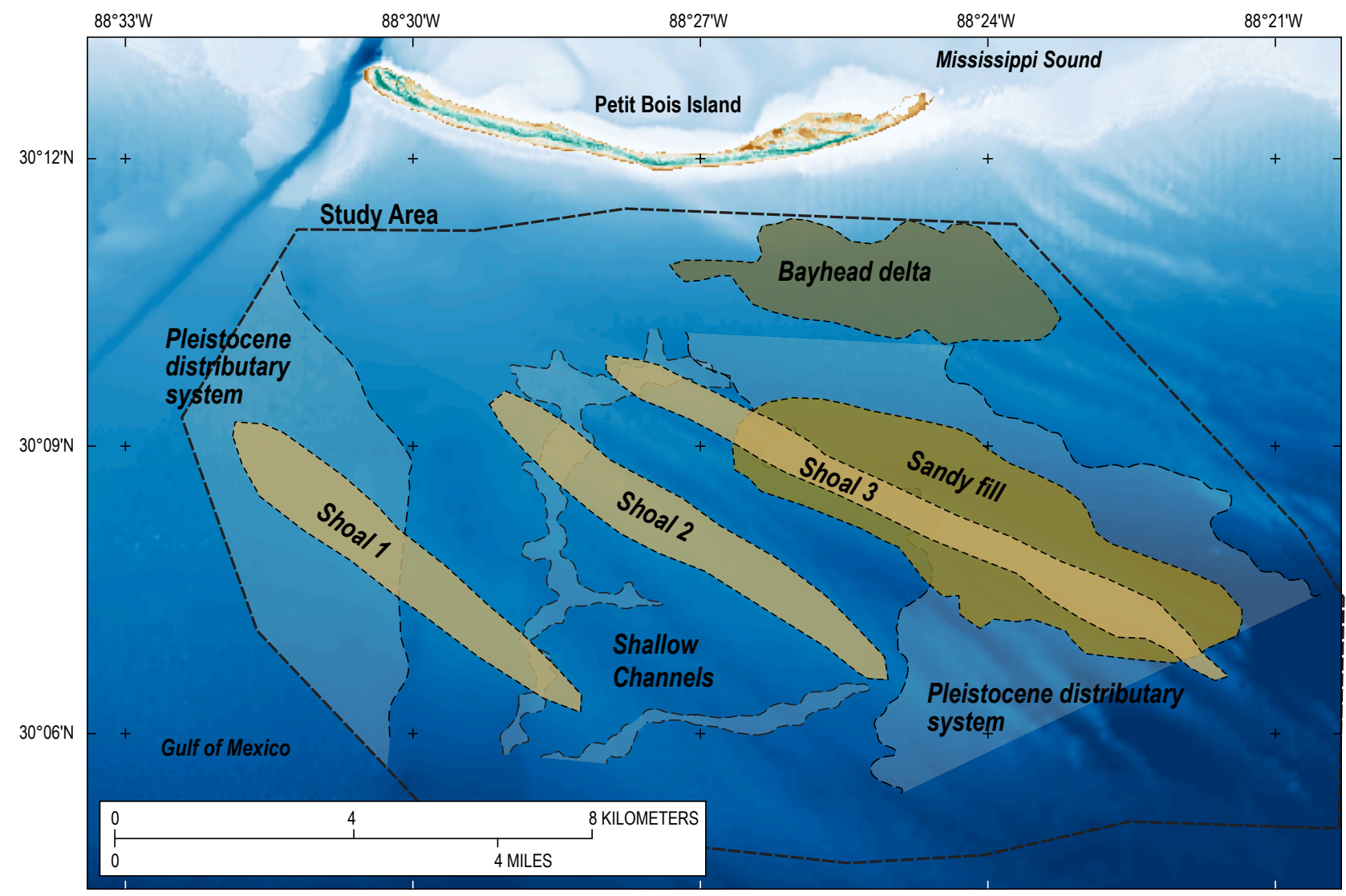

Figure 14. Significant features identified in this study include shoals and fluvial deposits. The buried Pleistocene fluvial deposits are large features but may have limited potential as sand resources dependent on depth to target and quality of overburden. The shoals are of significant in size, and if textural composition is compatible with the restoration area, there should be a high potential for sand resources. A combination of surface and subsurface features (such as shoal 3 and sandy fill) may also provide suitable material. Distance is expressed in kilometers $(\mathrm{km})$. Bathymetric image is 2007 DEM, with a 10-meter cell size and referenced to mean high water. Background map courtesy of the NOAA National Geophysical Data Center (NGDC) (http://www.ngdc.noaa.gov/dem/squareCellGrid/download/241). 


\section{Conclusion}

A geophysical investigation that included swath bathymetry, sidescan sonar, and chirp subbottom profiling was conducted on the inner shelf offshore of Petit Bois Island to investigate shoals and subsurface features. The study demonstrates that high-resolution geophysical surveys, groundtruth with sediment cores, can adequately characterize the near surface geology and provide information suitable for coastal restoration projects. The study identified several shoals, each averaging $1 \mathrm{~km}$ wide, $8 \mathrm{~km}$ long, and $4 \mathrm{~m}$ thick, surrounded by a thin $(\sim 1 \mathrm{~m})$ muddy sand sheet. Volumes of the shoals range from 20-24 $\times 10^{6} \mathrm{~m}^{3}$, with a sand content of 81 to 99 percent. These deposits rest on a thin (1-4 m) layer of marine sediments deposited as sea level last transgressed the area. Below this layer are deposits associated with Pleistocene distributary systems that crossed the study area during at least two former sea-level lowstands. These channels are infilled with transgressive material and relic fluvial deposits. Two predominant distributary systems are identified: a larger, older channel in the eastern portion of the study area, and a younger system to the west. The base horizon of the younger system truncates the older deposits, and the unit infills the low areas. Deposits within the distributary systems include a sandy-fill feature 2-9 m below the sea floor that contains $83 \times 10^{6} \mathrm{~m}^{3}$ of material, with a sand content of 83-97 percent, and bayhead delta deposits with a volume of $100 \times 10^{6} \mathrm{~m}^{3}, 2-5 \mathrm{~m}$ of overburden, and a sand content of 91 percent. Naturally, for sand resources, the overburden may limit accessibility to the deeper deposits, and the study demonstrates that targeting the intershoal areas may provide more direct access and a higher sand yield. However, as some of the overlying material includes portions of the shoals and sand sheets, the overburden may contribute to the overall sand volume.

The geologic framework developed in response to at least two sea-level cycles. A model to describe the geologic and morphologic development (fig. 17) begins with a sea-level lowstand within the Pleistocene (fig. 17A), that predates the last (oxygen isotope stage 2) lowstand. During this time distributary systems crossed the shelf and within the study area are preserved primarily in the eastern side; with sea-level rise the channels were infilled with sediment (fig. 17B). At the oxygen isotope stage 2 lowstand, distributary channels once again crossed the study area, incising the former fluvial deposits (fig. 17C). As in previous flooding events, these lowstand features were reworked and infilled during

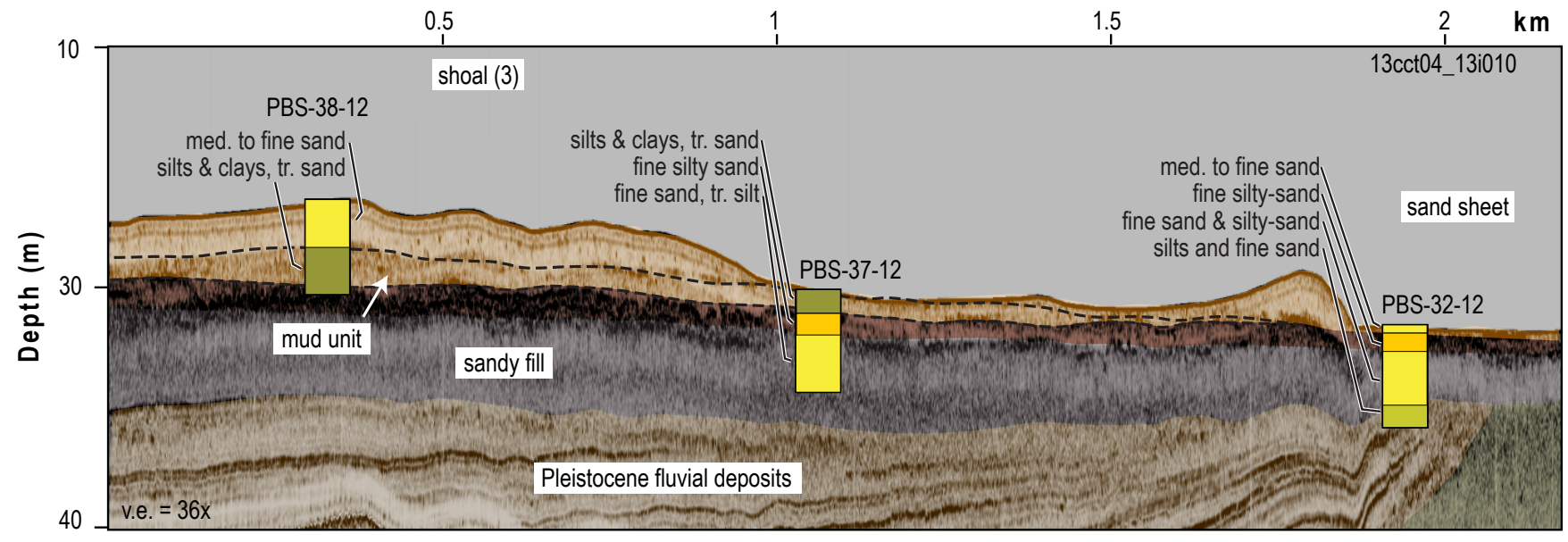

Figure 15. Seismic profile with sediment core overlay showing the extent of the mud unit at the base of the shoals. The mud unit contains only trace amounts of sand and reduces the total sand content of the shoals (table 2). Note that the core located in the inner shoal sand sheet (PBS-32-12) does not contain the mud unit and that it penetrates the underlying sandy fill. Location of the profile is shown in figures 7 and 16. Depth is expressed in meters $(\mathrm{m})$; distance is expressed in kilometers $(\mathrm{km})$. Vertical exaggeration is $36 \mathrm{x}$. 
the last sea-level rise (fig. 17D). At this time, transgressive sands covered the top of the deposits as sand sheets, and a prevailing southeasterly wave climate reworked these deposits into shoals, completing the morphological evolution of the inner shelf.

Table 2. Estimated sand volumes within the three main shoals (locations shown in fig. 7), adjusted to exclude the mud layer at the base of the shoals.

\begin{tabular}{ccccc}
\hline Deposit & $\begin{array}{c}\text { Shoal Total Volume } \\
\mathbf{x} 10^{6} \mathbf{~ m}^{3}\end{array}$ & $\begin{array}{c}\text { Volume Upper Unit } \\
\mathbf{x} 10^{6} \mathbf{~ m}^{3}\end{array}$ & $\begin{array}{c}\text { Avg. Sand Content } \\
\text { (percent) }\end{array}$ & $\begin{array}{c}\text { Shoal Sand Volume } \\
\mathbf{\times 1 0 ^ { 6 }} \mathbf{~ m}^{3}\end{array}$ \\
\hline Shoal 01 & 24.2 & 20.6 & 90 & 18.5 \\
Shoal 02 & 20.3 & 8.5 & 92 & 7.8 \\
Shoal 03 & 21.7 & 14 & 92 & 12.9 \\
\hline
\end{tabular}

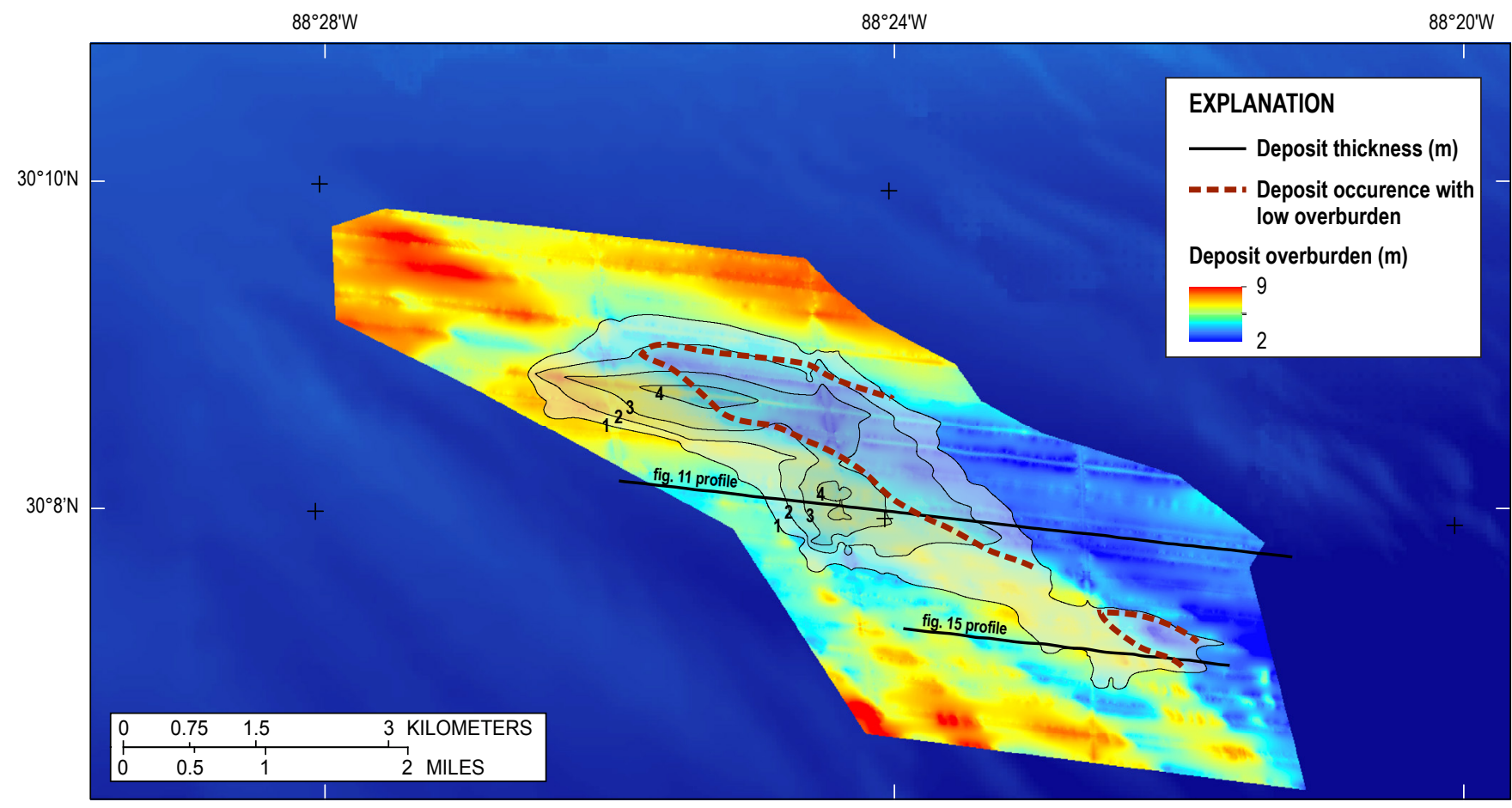

Figure 16. Isopach map (contours) of the sandy fill deposit shown in figures 11 and 15. The buried deposit is overlain by shoals and innershoal sand sheet; thickness of these deposits is shown as a color map. Red dashed lines outline areas where the thicker overburden can be avoided to excavate the sandy fill deposit. Depth and overburden are expressed in meters ( $\mathrm{m})$; distance is expressed in kilometers (km). Bathymetric image is 2007 DEM, with a 10-meter cell size and referenced to mean high water. Background map courtesy of the NOAA National Geophysical Data Center (NGDC) (http://www.ngdc.noaa.gov/dem/squareCellGrid/download/241). 
A. Sea-level Lowstand

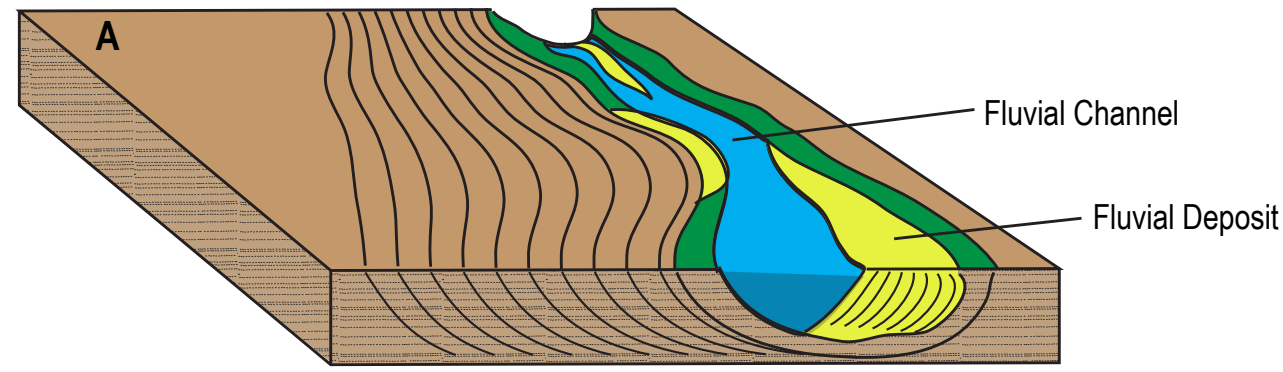

B. Sealevel Rise Inumndation

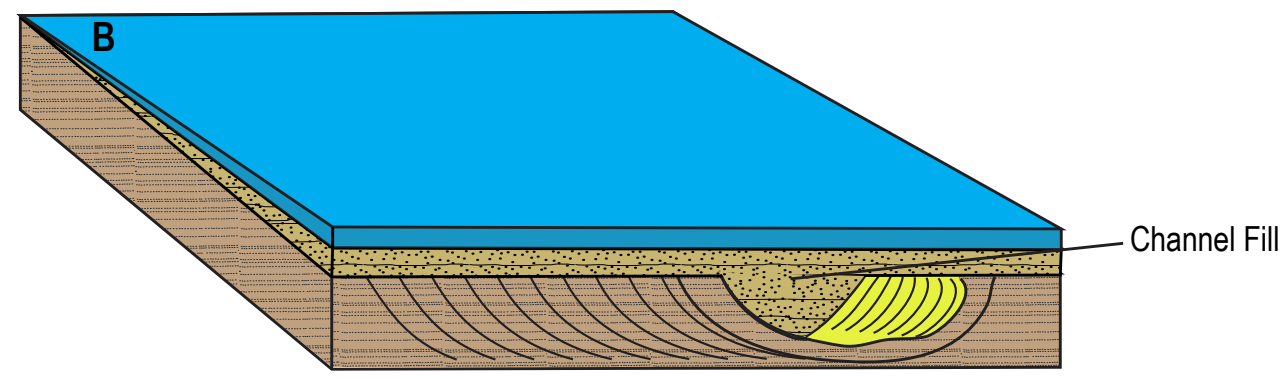

C. Sea-level Lowstand

(Oxygen Isotope Stage 2)

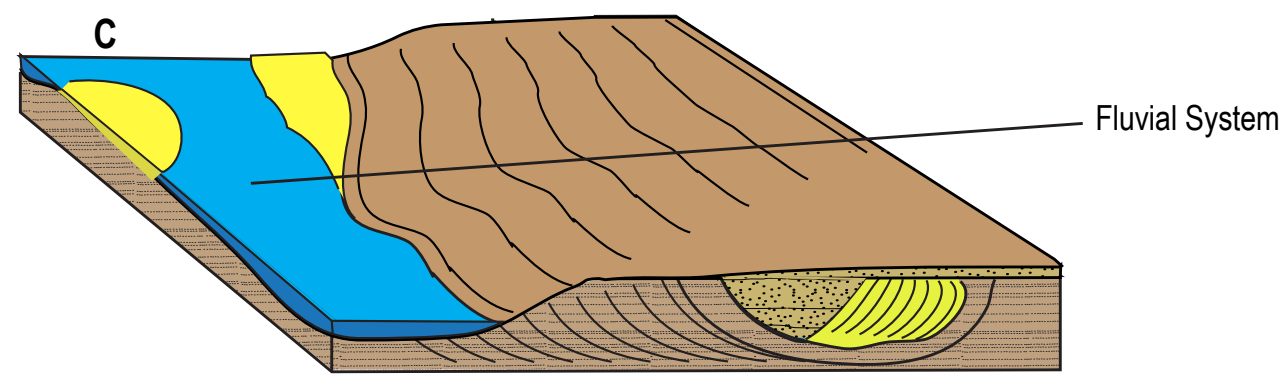

\section{Holocene Sea-level}

Rise Inundation

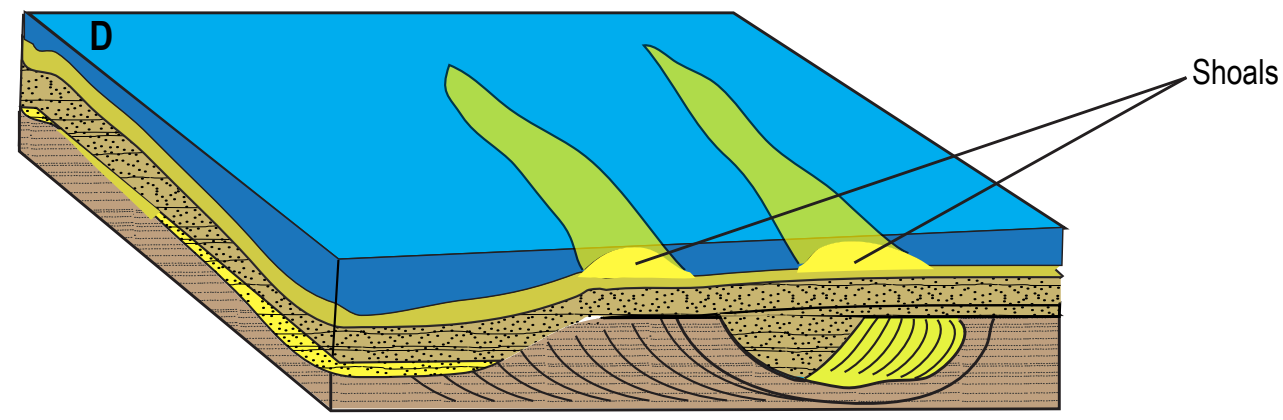

Figure 17. Conceptual model of the geologic development of the study area. A, Sea-level lowstand (prior to the last lowstand), distributary systems crossed the area to drain at the outer shelf. $B$, Sea-level rise flooded the fluvial deposits, infilling the former channels with sediment. $C$, The last sea-level lowstand (oxygen isotope stage 2), channels incised the former transgressive and fluvial deposits (the western edge of the channel shown extends beyond the study area). $D$, Holocene sea-level rise floods the study area, depositing transgressive sand sheets while wave-action reworked some former deposits into shoal systems. 


\section{References}

Alesce, M., Baehr, J., FitzHarris, M., Krick, J., and Murphy, P., 2014, Offshore sand borrow investigation, phases 1 and 2 -Geotechnical engineering report, app. A1 of U.S. Army Corps of Engineers Mobile District (USACE), 2014, Mississippi Coastal Improvements Program (MsCIP) comprehensive barrier island restoration-Hancock, Harrison, and Jackson Counties, MississippiDraft supplemental environmental impact statement: Mobile, Alabama, USACE, variously paged. [Also available at http:/www.sam.usace.army.mil/Portals/46/docs/program_management/mscip/docs/ Appendix\%20A1\%20-\%20MsCIP\%20Geotech\%20Report_FINAL\%20DRAFT.pdf.]

Bart, P.J., and Anderson, J.B., 2004, Late Quaternary stratigraphic evolution of the Alabama and west Florida outer continental shelf, in Anderson, J.B. and Fillon, R.H., eds., Late Quaternary stratigraphic evolution of the northern Gulf of Mexico margin: Tulsa, Okla., Society of Sedimentary Geology, Special publication, v. 79, p. 43-55. [Also available at http://dx.doi.org/10.2110/pec.04.79.0043.]

Bartek, L.R., Cabote, B.S., Young, Tonja, and Schroeder, William, 2004, Sequence stratigraphy of a continental margin subjected to low-energy and low-sediment-supply environmental boundary conditions - Late Pleistocene-Holocene deposition offshore Alabama, U.S.A., in Anderson, J.B., and Fillon, R.H., eds., Late Quaternary stratigraphic evolution of the northern Gulf of Mexico: Tulsa, Okla., Society of Sedimentary Geology, Special publication, v. 79, p. 85-109. [Also available at http:// dx.doi.org/10.2110/pec.04.79.0085.]

Bonisteel-Cormier, J.M., Nayegandhi, Amar, Wright, C.W., Sallenger, A.H., Brock, J.C., Nagle, D.B., Klipp, E.S., Vivekanandan, Saisudha, Fredericks, Xan, and Segura, Martha, 2010, EAARL coastal topography_-Mississippi and Alabama barrier islands, post-Hurricane Gustav, 2008: U.S. Geological Survey Data Series 556, 1 DVD. [Also available at http://pubs.er.usgs.gov/publication/ds556.]

Buster, N.A., and Morton, R.A., 2011, Historical bathymetry and bathymetric change-MississippiAlabama coastal region 1847-2009: U.S. Geological Survey Scientific Investigations Map 3154, 17 p., 1 pl., accessed June 01, 2014, at http://pubs.er.usgs.gov/publication/sim3154.

Byrnes, M.R., Rosati, J.D., Griffee, S.F., and Berlinghoff, J.L., 2013, Historical sediment transport pathways and quantities for determining an operational sediment budget-Mississippi Sound barrier islands in Brock, J.C., Barras, J.A., and Williams, S.J., Understanding and predicting change in the coastal ecosystems of the northern Gulf of Mexico: Coconut Creek, Fla., Coastal Education \& Research Foundation, Journal of Coastal Research special issue, no. 63, p. 166-183. [Also available at http://dx.doi.org/10.2112/si63-014.1.]

Doyle, L.J. and Sparks, T.N., 1980, Sediments of the Mississippi, Alabama, and Florida (MAFLA) continental shelf: Journal of Sedimentary Petrology, v. 50, no. 3, p. 905-915. [Also available at http://dx.doi.org/10.1306/212f7b1c-2b24-11d7-8648000102c1865d.]

Flocks, J.G., Kelso, K.W., Twichell, D.C., Buster, N.A., and Baehr, J.N., 2011a, Offshore sand-shoal development and evolution of Petit Bois Pass, Mississippi-Alabama barrier islands, Mississippi, USA, in Wang, Ping, Rosati, J.D., and Roberts, T.M., The proceedings of the Coastal sediments 2011Miami, Florida, USA, 2 May-6 May 2011: International Symposium on Coastal Engineering and Science of Coastal Sediment Processes, 7th, Miami, Fla., 2011, 3 v., 13p. [Also available at http://dx.doi.org/10.1142/9789814355537_0163.] 
Flocks, J.G., Ferina, N.F., Kindinger, J.L., 2011b, Recent geologic framework and geomorphology of the Mississippi-Alabama shelf, northern Gulf of Mexico, in Buster N.A., and Holmes, C.W., eds., Gulf of Mexico, origins, waters and biota, volume 3-Geology: College Station, Tex., Texas A\&M University Press, p. 157-174.

Flocks, J.G., Sanford, Jordan, and Smith, J.L., 2010, Sediment distribution on the Mississippi-Alabama shelf, northern Gulf of Mexico: U.S. Geological Survey Open File Report 2010-1002, 43p., accessed June 01, 2014, at http://pubs.er.usgs.gov/publication/ofr20101002.

Forde, A.S., Flocks, J.G., Kindinger, J.L, Bernier, J.C., Kelso, K.W., and Wiese, D.S., in press, Archive of digital chirp subbottom profile data collected during USGS cruise 13CCT04 offshore of Petit Bois Island, Mississippi, August 2013: U.S. Geological Survey Data Series, 3 DVDs, accessed June 01, 2014.

Forde, A.S., Dadisman, S.V., Flocks, J.G., Wiese, D.S., DeWitt, N.T., Pfeiffer, W.R., Kelso, K.W., and Thompson, P.R., 2011, Archive of digital chirp subbottom profile data collected during USGS cruises 10CCT01, 10CCT02, and 10CCT03, Mississippi and Alabama Gulf Islands, March and April 2010: U.S. Geological Survey Data Series 611, 11 DVDs. [Also available at http://pubs.usgs.gov/ds/611/.]

Fritz, H.M., Blount, Chris, Sokoloski, Robert, Singleton, Justin, Fuggle, Andrew, McAdoo, B.G., Moore, Andrew, Grass, Chad, and Tate, Banks, 2007, Hurricane Katrina storm surge distribution and field observations on the Mississippi Barrier Islands: Estuarine, Coastal and Shelf Science, v. 74, nos. 1-2, p. 12-20. [Also available at http://dx.doi.org/10.1016/j.ecss.2007.03.015.]

Greene, D.L., Jr., Rodriguez, A.B., and Anderson, J.B., 2007, Seaward-branching coastal-plain and piedmont incised-valley systems through multiple sea-level cycles_-Late Quaternary examples from Mobile Bay and Mississippi Sound, U.S.A.: Journal of Sedimentary Research, v. 77, no. 2, p. 139-158. [Also available at http://dx.doi.org/10.2110/jsr.2007.016.]

Kelso, K.W., and Flocks, J.G., 2015, Archive of sediment data from vibracores collected in 2010 offshore of the Mississippi barrier islands: U.S. Geological Survey Data Series 903. [Also available at http://dx.doi.org/10.3133/ds903.]

Kindinger, J.L., Balson, P.S., and Flocks, J.G., 1994, Stratigraphy of the Mississippi-Alabama shelf and the Mobile River incised valley system, in Dalrymple, R.W., Boyd, Ron, and Zaitlin, B.A., eds., Incised-Valley Systems - Origin and Sedimentary Sequences: Tulsa, Okla., Society for Sedimentary Geology, special publication no. 51, p. 83-95. [Also available at http://dx.doi.org/10.2110/ pec.94.12.0083.]

Kindinger, J.L., Miselis, J.L., and Buster, N.A., 2014, The shallow stratigraphy and sand resources offshore from Cat Island, Mississippi: U.S. Geological Survey Open-File Report 2014-1070, 74 p., accessed June 01, 2014, at http://dx.doi.org/10.3133/ofr20141070.

McBride, R.A., Anderson, L.C., Tudoran, Andrei, and Roberts, H.H., 1999, Holocene stratigraphic architecture of a sand-rich shelf and the origin of linear shoals - Northeastern Gulf of Mexico, in Isolated shallow marine sand bodies-Sequence stratigraphic analysis and sedimentologic interpretation: Tulsa, Okla., Society for Sedimentary Geology, special publication, v.64, p. 95-126. [Also available at http://dx.doi.org/10.2110/pec.99.64.0095.] 
Morton, R.A., 2007, Historical changes in the Mississippi-Alabama Barrier Islands and the roles of extreme storms, sea level, and human activities: U.S. Geological Survey Open-File Report 2007-1161, 38 p., accessed June 01, 2014, at http://pubs.usgs.gov/of/2007/1161/.

Morton R.A., and Rogers, B.E., 2009, Geomorphology and depositional subenvironments of Gulf Islands National Seashore, Mississippi: U.S. Geological Survey Open-File Report 2009-1250, 4 maps (varied scales), accessed June 01, 2014, at http://pubs.usgs.gov/of/2009/1250/.

Otvos, E.G., and Carter, G.A., 2008, Hurricane degradation-Barrier development cycles, northeastern Gulf of Mexico - Landform evolution and island chain history: Journal of Coastal Research, v. 24, no. 2, p. 463-478. [Also available at http://dx.doi.org/10.2112/06-0820.1.]

Otvos, E.G. and Giardino M.J., 2005, Interlinked barrier chain and delta lobe development, northern Gulf of Mexico: Sedimentary Geology, v. 169, nos. 1-2, p. 47-73. [Also available at http://dx.doi.org/10.1016/j.sedgeo.2004.04.008.]

Otvos, E.G., 1981, Barrier island formation through nearshore aggradation-Stratigraphic field evidence: Marine Geology, v. 43, nos. 3-4, p. 195-243. [Also available at http://dx.doi.org/10.1016/0025-3227(81)90181-x.]

Pendleton, E.A., Baldwin, W.E., Danforth, W.W., Dewitt, N.T., Forde, A.S., Foster, D.S., Kelso, K.W., Pfeiffer, W.R., Turecek, A.M., Flocks, J.G., Twichell, D.C., 2010, Geophysical data from offshore of the Gulf Islands National Seashore, Cat Island to Western Horn Island, Mississippi: U.S. Geological Survey Open-File Report 2010-1178, accessed June 01, 2014, at http://pubs.er.usgs.gov/publication/ofr20101178.

Pfeiffer, W.R., Flocks, J.G., DeWitt, N.T., Forde, A.S., Kelso, K.W., Thompson, P. R., and Wiese, D.S., 2011, Archive of side scan sonar and swath bathymetry data collected during USGS cruise 10CCT02 offshore of Petit Bois Island including Petit Bois Pass, Gulf Islands National Seashore, Mississippi, March 2010: U.S. Geological Survey Data Series 577, 1 DVD, accessed June 01, 2014, at http://pubs.er.usgs.gov/publication/ds577.

Sydow, J., and Roberts, H.H., 1994, Stratigraphic framework of a Late Pleistocene shelf-edge delta, northeast Gulf of Mexico: American Association of Petroleum Geologists Bulletin, v. 78, no. 8, p. 276-312. [Also available at http://dx.doi.org/10.1306/a25fead1-171b-11d7-8645000102c1865d.]

Twichell, David, Pendleton, Elizabeth, Baldwin, Wayne, Foster, David, Flocks, James, Kelso, Kyle, DeWitt, Nancy, Pfeiffer, William, Forde, Arnell, Krick, Jason, and Baehr, John, 2011, The shallow stratigraphy and sand resources offshore of the Mississippi barrier islands: U.S. Geological Survey Open-File Report 2011-1173, 61p., accessed June 01, 2014, at http://pubs.usgs.gov/of/2011/1173/. 
